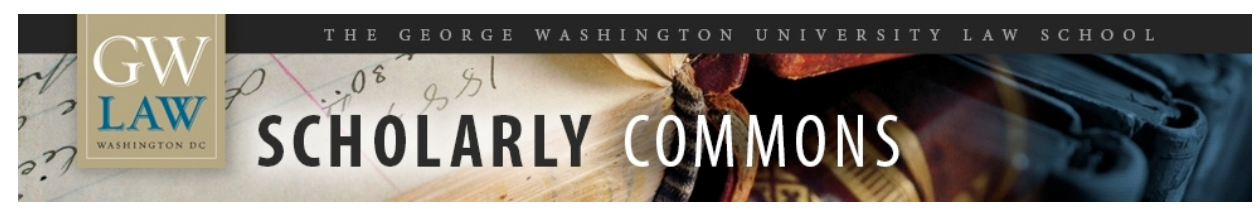

\title{
Good Deficits: Protecting the Public Interest From Deficit Hysteria
}

Neil H. Buchanan

George Washington University Law School, neilhbuchanan@gmail.com

\section{Recommended Citation}

31 Virginia Tax Review 75 (2011)

This Article is brought to you for free and open access by the Faculty Scholarship at Scholarly Commons. It has been accepted for inclusion in GW Law Faculty Publications \& Other Works by an authorized administrator of Scholarly Commons. For more information, please contact spagel@law.gwu.edu. 


\title{
GOOD DEFICITS: PROTECTING THE PUBLIC INTEREST FROM DEFICIT HYSTERIA
}

\author{
Neil H. Buchanan*
}

President Obama has come under increasingly fierce criticism for the size of the federal budget deficit, as both Democratic and Republican politicians loudly proclaim that federal spending should be cut. This article explains why such anti-deficit fervor is misguided and simplistic, and why, perhaps counter-intuitively, cutting government spending can hurt the country, rather than help it, in both the short run and the long run.

In the short run, cutting deficit spending can be disastrous for the economy, especially if the economy is already in a weakened state (as the U.S. economy has been since 2008). In addition, the federal budget fails to separate spending that provides long-term benefits to the economy - such as spending on education and infrastructure - from spending that provides no long-term benefits. It is, therefore, just as politically expedient to cut valuable spending as it is to cut waste: both types of spending cuts reduce "the deficit." Thus, indiscriminate cuts in government spending will reduce the deficit, but will also harm our long-term prospects.

This article proposes a novel solution to this problem: the creation of an independent agency to fix the current incoherent and damaging budgeting process. The proposed "Growth Budgeting Board" could eliminate poorly timed and poorly targeted spending cuts, protect valuable investments from the budget ax, and discipline the budgeting process to

* Professor, The George Washington University Law School (Washington, D.C.), and Fellow, Monash University (Melbourne, Australia). J.D. University of Michigan Law School, Ph.D. in Economics, Harvard University. I would like to thank Sarah Lawsky, Reuven Avi-Yonah, Cheryl Block, Michael C. Dorf, James R. Hines, Jr., Kyle D. Logue, Henry Ordower, Lisa Philipps, Kerry Ryan, Daniel N. Shaviro, Peter Weidenbeck, Bonnie Wilson, faculty audiences at the law schools at Boston College, Hastings, Rutgers-Newark, Saint Louis University, the University of Wisconsin, and participants in the 2007 Critical Tax Conference and the 2009 Washington University Law School Symposium on Fiscal Policy. Superior research assistance was provided by Katherine Dimengo, John Katsos, Ketan Pastakia, Ashley Parr, Leah Patrick, Samuel Roe, Phillip Spinella, and Kathryn Vertigan. 
reduce the opportunities for political gamesmanship and abuse.

\section{TABLE OF CONTENTS}

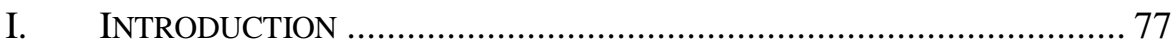

II. Budget Deficits: What They ARE, AND How Big They

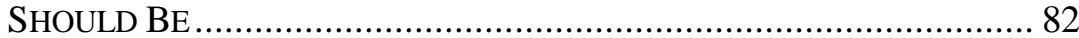

A. Measuring Deficits and Debt ............................................... 83

B. The Possible Harms of Fiscal Deficits .................................. 86

1. Deficits, National Bankruptcy, and Inflation .................... 87

2. Deficits, Investment, and Future Prosperity ...................... 88

3. Deficits and the Risks of a Financial Crisis ..................... 89

C. Deficit Targets ................................................................... 94

1. Balanced Budgets ........................................................ 95

2. Percentage Targets and the Debt-to-Income Ratio............. 96

III. GOOD DEFICITS IN THE SHORT RUN: FIGHTING RECESSIONS........... 98

A. Weak Economies Need Help to be Brought Back to Life.......... 99

B. Possible Economic Damage from Reducing Deficits............. 101

C. Deficits Use Resources that Would Otherwise Lie Idle.......... 105

D. The Increase in Overall Debt During Recessions is Sustainable ......................................................................... 105

IV. GOOD DEFICITS IN THE LONG RUN: ENHANCING GROWTH ........... 106

A. The Tradeoff Between Government and Business Spending:

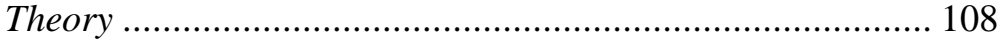

B. Capital Budgeting, Growth Budgeting, and Future

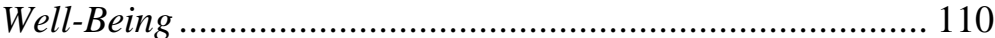

C. Capital Budgeting, the Golden Rule, and Growth

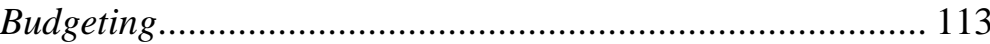

D. Some Examples: Investing in Children.................................. 114

E. The Advantages of Piecemeal Decision-Making..................... 116

V. FISCAL DiscIPLINE THROUGH AGENCY ACTION .......................... 117

A. Rejecting the Growth Budget Out of Hand............................ 117

B. Using and Abusing Capital Accounts................................... 119

C. Can Budget Abuses be Disciplined by the Political Process? ............................................................................ 122

1. Difficult Calls: War and Growth Budgeting ................... 122 
2. Independent Analysts and Official Estimates

D. Administrative Procedures

1. A Quasi-Judicial Process

2. Blue-Ribbon Commissions ............................................ 126

3. The Fiscal Fed …................................................... 128

4. The Growth Budgeting Board (GBB) ............................. 129

E. Pre-Screening and Post Mortem Assessments ...................... 131

V. CONCLUSION.

\section{INTRODUCTION}

"Cutting the deficit by gutting our investments in innovation and education is like lightening an overloaded airplane by removing its engine. It may make you feel like you're flying high at first, but it won't take long before you feel the impact."

- President Barack Obama, The State of the Union Address, 2011 ${ }^{1}$

“All of this new government spending was sold as 'investment.' Yet after two years, the unemployment rate remains above $9 \%$ and government has added over $\$ 3$ trillion to our debt."

- U.S. Rep. Paul Ryan, Official Republican Response to the State of the Union Address, 2011 ${ }^{2}$

Spending by the federal government - even spending that is financed by deficits - can improve both short-term and long-term living standards for the citizens of the United States. This basic truth has not, unfortunately, stopped the U.S. political system from becoming paralyzed by a fear of deficit spending. Indeed, it is not an exaggeration to say that federal deficits were the defining issue of the first two years of Barack Obama's presidency, and federal budgeting issues have become an even more fiercely contested political battleground in the $112^{\text {th }}$ Congress.

This is hardly the first time that deficits have become such a central concern for policymakers, of course. The current environment, however, is

1 Office of the Press Sec'y, Remarks by the President in State of Union Address, THE White House (Jan. 25, 2011), http://www.whitehouse.gov/the-press-office/2011/01/25/ remarks-president-state-union-address.

2 Transcript: GOP Response From Rep. Paul Ryan, NAT'L Pub. RADIO (Jan. 25, 2011), http://www.npr.org/2011/01/26/133227396/transcript-gop-response-from-rep-paulryan. 
especially toxic, with the worst economic downturn since the Great Depression leading to extreme levels of economic pain and fear. ${ }^{3}$ Budget deficits are little more than an abstraction to most people, and unimaginably large dollar figures seem to validate suspicions that something big and bad must be going on. When combined with personal intuitions that borrowing money must somehow be a mark of shame, it is precisely the abstract nature of deficits that makes people fear and misunderstand them. Even anti-deficit policies that will harm the economy can be embraced by millions of scared and uncertain citizens.

The public's fear has, unsurprisingly, found a voice among the nation's politicians. One Republican U.S. Senator, for example, recently claimed in a floor debate that the current level of the federal deficit represents a "crisis" that threatens the country's security. ${ }^{4}$ A Democratic U.S. Senator cited Congress's failure "to deal with one of the greatest threats facing our nation: our exploding deficits and debt" as one of his major reasons for retiring in frustration from his office, ${ }^{5}$ and he listed deficit reduction first among the four problems that he would help the President try to solve during his remaining time in office. ${ }^{6}$

The constant hyping of the supposed harms flowing from budget deficits has reached the point where being loudly critical of deficits seems to have become a badge of seriousness, notwithstanding any particular commentator's lack of expertise about economics. To note just one example, the journalist Fareed Zakaria, who has a well-earned reputation as a keen observer of foreign affairs, especially with regard to the wars in the Middle East, felt comfortable inveighing against deficits in a commentary early in 2010, even though it is far from his area of expertise. Criticizing two prominent policymakers for failing to advocate a policy that would address "the black hole that is the federal budget deficit," Zakaria

3 See Bob Willis, U.S. Recession Worst Since Great Depression, Revised Data Show, BLOOMBERG, Aug. 1, 2009, http://www.bloomberg.com/apps/news?pid=newsarchive \&sid= aNivTjr852TI.

4 Floyd Norris, Rates Fall as Market Fears Economic Weakness, N.Y. TIMES, Aug. 15, 2010 ("Deficit hawks are leaning forward in the United States as well. 'Many Americans and most senators feel that the level of the federal debt is at crisis levels,' Senator Lamar Alexander, a Tennessee Republican, said in a Senate debate last month, adding that the debt 'threatens the security of our country.'").

5 Press Release, Bayh Announces He Will Not Seek a Third Senate Term (Feb. 15, 2010), available at http://www.swiahu.org/images/PDF/Bayh\%20Email.pdf.

${ }^{6}$ Id. (listing deficit reduction first, followed by "[getting] the economy moving again," financial reform, and educational reform).

7 Transcript, Fareed Zakaria GPS: Interview with Paul Volcker, CNN (Feb. 14, 2010), http://transcripts.cnn.com/TRANSCRIPTS/1002/14/fzgps.01.html. 
concluded: "For shame." While many people might find it odd if an economist were to weigh in on the wisdom of, say, the U.S. military's withdrawal strategy from Afghanistan, there seems to be little resistance to the idea that anyone with a microphone is qualified to denounce deficit spending.

Predictably, this constant denunciation of deficits feeds back into public opinion polls, with the public repeating what they have heard about the dangers of continued budget deficits. Polls show that large numbers of people continue to worry about budget deficits. ${ }^{9}$ For example, a poll in January 2010 showed over $80 \%$ of those interviewed describing themselves as either "very worried" or "somewhat worried" that "increasing federal debt will harm the financial future of your children and grandchildren,", 10 while $85 \%$ were either "angry" or "bothered, but not angry" about "the growing federal budget deficit." 11

The drumbeat against deficit spending can be heard everywhere, not just among the public and politicians, but among many policy commentators as well. ${ }^{12}$ Some commentators, in their zeal to advance policies to reduce deficits, twist the results of public opinion polls. For example, a poll that showed $14 \%$ of Americans identifying the deficit as "the largest problem the country will face" in twenty-five years was inaccurately (or at least misleadingly) described as showing that "Americans Believe Deficit is Largest Looming Problem."13

${ }^{8} I d$.

9 Summing Up Public Opinion on Federal Debt and Deficits, Pub. AgENDA (Feb. 25, 2010), available at http://www.publicagenda.org/files/pdf/SummingUpPublicOpinionOn DebtAndDeficits.pdf.

$10 I d$. at 2.

11 Id.

12 One of the D.C.-based think tanks that has been especially active in promoting the idea that deficits are an enormous, pressing problem is the Committee for a Responsible Federal Budget. This private group of former members of Congress and high-level budget officials from both parties issues ongoing commentary to support its overall claim that the U.S. fiscal situation must be changed - and changed quickly - through some combination of cuts in spending and increases in taxes. Because of the pedigrees of the members of that committee, and because it produces such a large amount of material warning against deficits, its analyses are an especially useful source for those who wish to find the more sophisticated versions of anti-deficit arguments. See generally The CommitTeE FOR A ResPOnSIBLE FEDERAL BudGeT, http://crfb.org/ (last visited Apr. 21, 2011).

13 Americans Believe Deficit is Largest Looming Problem, THE COMMITTEE FOR A RESPONSIBLE FEDERAL BudGeT (Mar. 16, 2010), http://crfb.org/blogs/americans-believedeficit-largest-looming-problem. The poll merely showed that more people - one in seven respondents - named the federal deficit as the biggest problem likely to face the country in twenty-five years. It did not show that Americans as a whole, or even a simple majority, 
Even in this atmosphere of misinformation and crisis, however, it is possible to find sensible, sober analyses of deficits, with some editorialists attempting to put the risks and tradeoffs of deficits in some perspective. ${ }^{14}$ Most prominent economists, moreover, generally agree that any problem with deficits is not a matter of the deficits that are being incurred in the midst of the current "Great Recession" but is, at most, a long-term problem. ${ }^{15}$ As two highly regarded economists recently put it: "Today's debt problems result not from how fiscal policy was managed during the crisis, but from how it was mismanaged before the crisis." "Another prominent economist described the hype surrounding budget deficits as "scare tactics," build-up to the U.S. invasion of Iraq in 2003. ${ }^{18}$

Even so, because the overall atmosphere in public discussions continues to be so stridently anti-deficit, President Obama has responded to the public's fears with gestures that are intended to suggest that he is taking action, but that instead tend to validate those fears. For example, early in

believe that to be true.

14 See, e.g., Editorial, What They're Not Telling You, N.Y. TIMES, Jul. 31, 2010 ("There is a lot of heated talk in Washington these days about the deficit, unfortunately little of it serious.").

15 For some contrary views, see infra note 77 . The most extreme theoretical claim against the standard view of deficit spending during recessions is the (misnamed) concept of "Ricardian Equivalence," which predicts that government spending is perfectly offset by rational taxpayers, who save dollar-for-dollar the amount of any increase in government spending, in anticipation of future tax increases. See, e.g., Brad DeLong, An Appeal for Help: Recent History of Economic Thought, Brad DeLong's Grasping Reality with AlL Ten TentaCles, Apr. 5, 2009, http://delong.typepad.com/sdj/2009/04/an-appeal-for-helprecent-history-of-economic-thought.html (professor in Berkeley's Economics Department saying that "Ricardian equivalence means not just that deficit-financed tax cuts have no short-term stimulative effects but also that deficit-financed spending increases have no shortterm stimulative effects on nominal spending," and describing that claim as "false").

16 Olivier Blanchard \& Carlo Cottarelli, The Great False Choice, Stimulus or Austerity, FIN. TIMES, Aug. 11, 2010 (chief economist and head of fiscal affairs at the IMF arguing that long-term fiscal changes in most countries are much more important "than if the world gets 2011 plans wrong by a fraction of a percent of GDP").

17 Paul Krugman, Fiscal Scare Tactics, N.Y. TIMES, Feb. 4, 2010, at A25 ("The deficit threatens economic recovery, we're told; it puts American economic stability at risk; it will undermine our influence in the world. These claims generally aren't stated as opinions, as views held by some analysts but disputed by others. Instead, they're reported as if they were facts, plain and simple. Yet they aren't facts.").

18 Id. ("To me - and I'm not alone in this - the sudden outbreak of deficit hysteria brings back memories of the groupthink that took hold during the run-up to the Iraq war. Now, as then, dubious allegations, not backed by hard evidence, are being reported as if they have been established beyond a shadow of a doubt."). 
2010, the President proposed a freeze on federal spending in certain areas of the budget. $^{19}$ More prominently, and perhaps of more ultimate consequence, the President issued an executive order creating a bipartisan commission to study the federal deficit and debt and to produce a report and recommendation after the 2010 mid-term elections. ${ }^{20}$

In this atmosphere, the better response to public concerns about the deficit involves two steps. First, we need to clearly differentiate short-run changes in the deficit from long-run changes and guarantee that short-run policies will truly be limited to the short-run. This will allow policymakers to respond to recessions with appropriate levels and types of fiscal stimulus (i.e., "good deficits"), without fear of being told that it is unacceptable to add to "the deficit." Second, we need to remind ourselves that long-run deficits can also be good, so long as they are spent on projects that represent an investment in the nation's future productivity, and we need to put in place mechanisms that will increase the government's long-term investments in the economy.

This article, while acknowledging the dangers of certain types and levels of federal deficit spending, describes the conditions under which deficit spending can be "good" - that is, when deficits will improve the economy's performance and people's standards of living - in both the short-run and the long-run. Given the inability of the U.S. political system to deal with budget issues in a coherent manner - or even to understand them - I propose the adoption of an independent federal agency charged with providing essential guidance regarding government spending and

19 Lori Montgomery, Obama to Propose Freeze on Government Spending, WASH. Post, Jan. 26, 2010 ("Under mounting pressure to rein in mammoth budget deficits, President Obama will propose in his State of the Union address a three-year freeze on federal funding that is not related to national security, a concession to public concern about government spending that could dramatically curtail Obama's legislative ambitions."). Note the use of the loaded adjective "mammoth" in what is supposed to be a news article, not an editorial.

20 Exec. Order No. 13,531, 75 Fed. Reg. 7, 927 (Feb. 23, 2010), available at http://edocket.access.gpo.gov/2010/pdf/2010-3725.pdf; see also Alex Kingsbury, Obama Creates a Commission to Shrink the Deficit, U.S. News \& WORLD REP., Feb. 22, 2010 ("There's an old maxim in Washington that when politicians are either unable or unwilling to tackle a problem directly, they appoint a commission to give the issue more intensive study. So it was last week when President Obama created the National Commission on Fiscal Responsibility and Reform, a bipartisan group of 18 souls charged with solving perhaps the country's most vexing and pressing public-policy problem — red ink.”). That commission's report was, indeed, issued shortly after the November 2010 elections. See THE NAT'l Comm'n on Fiscal Responsibility and Reform, The Moment of Truth (2010), available at http://www.fiscalcommission.gov/sites/fiscalcommission.gov/files/documents/ TheMomentofTruth12_1_2010.pdf. 
taxation. Specifically, the agency - the "Growth Budgeting Board" would be empowered to identify those budgetary items (both spending programs and tax cuts) that could responsibly be financed through increases in the public debt. With such a board in place, it would be possible to stop making foolish decisions about spending — decisions that in the current environment are based on little more than intuition and superstition - and instead to allow policy to be based on clear understandings of how the deficit affects the economy, both now and in the future.

\section{Budget Deficits: What They ARE, AND How Big They Should Be}

Studying the connections between fiscal deficits and economic prosperity is one of the foundational purposes of modern macroeconomics. $^{21}$ As the discussion above demonstrates, there is a recurring focus within U.S. political and policy circles on reducing the federal government's budget deficit, a focus that has become especially intense in the last two years. The issue is usually presented as a matter of high national priority, often presented in moral terms and almost invariably described as a matter of protecting the country's long-term economic health. ${ }^{22}$ The idea is to force reluctant politicians to make "tough choices" that might not be popular, but that are necessary for the good of the country, the economy, and "our children and grandchildren." What is usually missing from such calls for austerity, however, is any but the most casual explanation of why deficits matter, much less how to determine the appropriate level of the federal deficit.

These issues are anything but simple. There are several competing candidates for the right way to measure deficits, ${ }^{23}$ and there is a dearth of positive guidance from macroeconomic theory to tell us what the deficit should be in any given year or over longer periods of time. There is,

21 See, e.g., Alan S. Blinder, Is the National Debt Really - I Mean, Really - a Burden?, in DebT AND THE Twin Deficits Debate 209, 219 (James M. Rock ed., 1991); Neil H. Buchanan, Is It Sometimes Good to Run Budget Deficits? If So, Should We Admit It (Out Loud)?, 26 VA. TAX REv. 325, 335-37 (2006) [hereinafter Buchanan, Sometimes Good?].

22 See, e.g., Gray Rohrer, George LeMieux: We Can, We Must, Balance Federal Budget, Sunshine St. News, Aug.12, 2010, http://www.sunshinestatenews.com/story/ george-lemieux-we-can-we-must-balance-federal-budget (reporting Robert Bixby's claim that the deficit is "not a numbers issue, it's a moral issue").

23 See, e.g., Neil H. Buchanan, Debt, Deficits, and Fiscal Policy: Three Essays (1996) (unpublished Ph.D dissertation, Harvard University), ch. 1 [hereinafter Debt, Deficits, and Fiscal] (discussing thirteen different ways to measure government deficits - a discussion that did not purport to cover all of the possibilities). 
however, some very important negative guidance from macroeconomic theory. That is, even though we do not know what the right answer is, we can rule out some widely believed wrong answers. In the end, however, several possible deficit targets are not obviously wrong, making the debate about "responsible" budgets much more difficult than it might initially appear.

\section{A. Measuring Deficits and Debt}

Before beginning to analyze the various approaches to government budget management, it is important to highlight the difference between deficits and debt. A deficit is the difference in a given time period (usually a year) between the amount of money that the federal government spends and the amount of money that it receives. ${ }^{24}$ (A negative deficit, with revenues exceeding expenditures, is called a surplus.) If the federal government runs a deficit in a given year, the U.S. Treasury finances that deficit by selling government securities to "the public," which includes all non-federalgovernment entities, ${ }^{25}$ including private individuals, state and local governments, private corporations, financial institutions (pension funds, mutual funds, banks, etc.), and foreign governments. By contrast, the federal debt is the total amount of money that the federal government owes at a given time to those other entities, also called "debt held by the public." 26 The debt is thus the accumulated value, at any point in time, of all previous annual deficits (less previous annual surpluses), plus accumulated interest on the money borrowed.

The deficit, therefore, is financed by an increase in the outstanding debt of the federal government. Entities lend money to the U.S. government by

24 This measure of the deficit is also called the "cash-flow deficit," because it simply measures the difference between money flowing into the government and money flowing out of the government during a given year.

25 For purposes of budget accounting, however, the Federal Reserve System is considered to be part of "the public."

26 The U.S. "national debt" is typically expressed in two forms: as the total value of all Treasury securities that have been issued and not redeemed, or as the total value of the Treasury securities held outside of the federal government. Because federal agencies hold large amounts of securities issued by the U.S. Treasury - which is merely another federal agency - this internal accounting procedure is akin to merely keeping an IOU in one pocket that promises to transfer money at some point from another pocket. That is, the overall federal debt is not affected by these internal accounting procedures. On August 19, 2010, the total federal debt (including debt held internally by federal agencies) was $\$ 13.4$ trillion, or $92 \%$ of GDP; but the debt held by the public was $\$ 8.8$ trillion, or $60 \%$ of GDP. See Treasury Direct: The Debt to the Penny and Who Holds It, http://www.treasurydirect. gov/NP/BPDLogin?application=np (last visited Aug. 21, 2010). 
buying Treasury securities that legally obligate the federal government to repay the borrowed funds, with interest, at a specific date or dates in the future. These securities, often called "Treasuries" because they are issued by the United States Department of the Treasury, carry the full faith and credit of the United States government. They are simply loan instruments, with a private party exchanging money today for the promise of money in the future.

Understanding the fundamental difference between deficit and debt is necessary to understand even the most basic issues regarding fiscal budgeting. In addition, there are several important nuances regarding the measurement of deficits and debt. ${ }^{27}$ For example, it is essential not to discuss deficits and debt in dollar terms but as the percent of the nation's income that they represent. This is because richer borrowers are better positioned to repay any given amount of debt than poorer borrowers would be. ${ }^{28}$ For purposes of discussing government debt, the best measure of national income is the gross domestic product. ${ }^{29}$ This means, for example, that the $\$ 160.7$ billion deficit in 2007 was much smaller than the $\$ 149.7$ billion deficit in 1987, because GDP was $\$ 13,896$ billion in 2007 but only $\$ 4,651$ billion in 1987 , making the debt-to-GDP ratios in those years $1.2 \%$

27 For a short discussion of the various issues discussed here, see Neil H. Buchanan, If We Must Obsess About Budget Deficits, Can We At Least Measure Them Correctly?, FindLAw, Jan. 28, 2010, http://writ.news.findlaw.com/buchanan/20100128.html [hereinafter Buchanan, If We Must Obsess]. There is also a method of measuring deficits that focuses on aggregating all future deficits into a single number, rather than measuring deficits year by year. This is discussed and critiqued in Neil H. Buchanan, Social Security, Generational Justice, and Long-Term Deficits, 58 TAX L. REv. 275, 291 (2005) [hereinafter Buchanan, Long-Term Deficits]. The analysis herein will not further address issues related to that alternative measurement of national indebtedness.

28 U.S. Gov't Accountability OfFice, Federal Debt: Answers to Frequently ASKED QUESTIONS: AN UPDATE (2004), available at http://www.gao.gov/new.items/d04485 sp.pdf ("The amount of any borrower's debt by itself is not a good indicator of the burden imposed by that debt. A borrower's income and wealth are important in assessing the burden of debt. Therefore, to get a sense of the burden represented by the federal debt, that debt is often measured in relation to the nation's income."); see also Buchanan, Long-Term Deficits, supra note 27 , at 289-91.

29 There are various measures of an economy's annual income, but the most common measure is Gross Domestic Product, or GDP. U.S. Gov't ACCOUNTABILITY OfFICE, supra note 28, at 7. ("Gross domestic product (GDP) is a commonly used measure of domestic national income. GDP is the value of all goods and services produced within the United States in a given year and is conceptually equivalent to incomes earned in production. It is a rough indicator of the economic earnings base from which the government draws its revenues.”). 
and $3.2 \%$ respectively. ${ }^{30}$

While discussions of the U.S. budget deficit almost always focus on the federal government to the exclusion of state and local governments, there is no valid theoretical reason to separate the government's effects on the economy on the basis of our federal form of government. If the government spends, it does not matter for macroeconomic purposes whether that spending comes from a state, a city, or any other government entity. ${ }^{31}$ Because states and cities currently face severe budget difficulties, their efforts to raise taxes and cut spending substantially offset some or all of the federal government's actions. For example, "when the federal government was adding \$234 billion in 2008 to the ... deficit in order to fight the worsening recession, states were cutting $\$ 193$ billion." 32 The net difference was $\$ 41$ billion, less than $0.3 \%$ of GDP, making the overall impact of the federal government's efforts to help the economy much smaller than they appeared.

Most important, the federal deficit automatically rises when the economy shrinks, because as people lose jobs, they pay fewer dollars in taxes and receive more dollars in government assistance. The size of this effect can be substantial. For example, in 2009, when the federal deficit rose by $\$ 955$ billion, or $6.7 \%$ of GDP, almost one-third of that change was due to the decline in revenues and increase in expenditures that accompanied the worsening recession. ${ }^{33}$ More generally, in the six recessions that preceded the current downturn, the deficit rose on average by $2.2 \%$ of GDP, but almost three-quarters of that amount (1.6\%) was due to cyclical changes in the economy. ${ }^{34}$

From the standpoint of deficit policy, therefore, it is essential during a recession for the government to take account of how much of the change in the deficit is due to the worsening economy. This is known as the "standardized employment deficit" or the "cyclical deficit," which measures

30 Cong. Budget Office, Budget and Economic Outlook: Historical Budget DATA, tbls. F-1, F-11, F-2 (2010), available at http://cbo.gov/ftpdocs/108xx/doc10871/ HistoricalTables.pdf.

31 See Buchanan, Long-Term Deficits, supra note 27, at 291.

32 Buchanan, If We Must Obsess, supra note 27.

33 Id.

34 Cong. Budget Office, The Budget and Economic Outlook: Fiscal Years 2008 TO 2018, app. at 129, box C-1, (2008), available at http://cbo.gov/ftpdocs/89xx/doc8917/0123-2008_BudgetOutlook.pdf. Note that the denominator for these percentages is "potential GDP," which is the level of GDP that would have been produced had the economy not been in a recession. 
how large the deficit would have been but for the recession. ${ }^{35}$ In addition, any temporary spending that is incurred to fight the deficit, but that will not continue after the recession is over, must be separated from the rest of the deficit. Only if those two adjustments are made can spending and taxing policy be undertaken with a clear understanding of the various reasons that the deficit has risen during a recession.

The current political environment fails to differentiate between deficits that are due to long-term imbalances, deficits that are due to short-term passive effects of the economy on spending and revenues, and deficits undertaken specifically to reverse an economic downturn on a temporary basis. In this article, I argue that it is essential to have a government agency to provide relevant guidance to Congress.

\section{B. The Possible Harms of Fiscal Deficits}

As discussed above, there are a number of plausible methods to measure the official "deficit" of the U.S. government, and the most commonly cited measure (the "cash-flow deficit") is not a particularly strong one. ${ }^{36}$ Even so, the standard political debate in the U.S. takes as a given that the deficit is too high, and therefore that the level of government spending must be cut, or that taxes must be increased, or both. For some politicians, however, tax increases are off the table, for reasons that are not germane to this discussion. ${ }^{37}$ In any case, calls to bring the deficit (however measured) under control imply some combination of lower government spending and higher taxes. Before continuing, therefore, it is important to discuss the potential benefits of reducing deficits, that is, the arguments against deficits. ${ }^{38}$

35 Id.

36 Buchanan, If We Must Obsess, supra note 27.

37 See, e.g., David Edwards \& Daniel Tencer, Sen. Kyl: \$678-billion Tax Break for Rich Should not be Offset, THE RAW STORY (July 11, 2010), http://www.rawstory.com/rs/ 2010/07/11/kyl-you-offset-tax-cuts/ (U.S. Senate Minority Whip arguing "you should never raise taxes in order to cut taxes"). In addition, some politicians continue to assert that tax cuts do not increase the deficit at all. See, e.g., Luke Johnson, Marco Rubio: Tax Cuts Pay for Themselves While Unemployment Benefits Don't, THE FlA. InDEP., July 20, 2010, http://floridaindependent.com/4319/marco-rubio-tax-cuts-pay-for-themselves-whileunemployment-benefits-don\%E2\%80\%99t. Some readers will recognize this argument as the so-called Laffer Curve, which has been broadly rejected by the economics profession. See, e.g., Buchanan, Sometimes Good?, supra note 21, at 341 (quoting N. Gregory Mankiw as having "ridiculed the supply-side tax policies of President Ronald Reagan as the work of 'charlatans and cranks.'").

38 The harms from cutting deficits are discussed in Part III below. 
1. Deficits, National Bankruptcy, and Inflation

While there are, as noted above, many calls to reduce deficit spending that seem to flow from the unexamined belief that there is something intrinsically wrong with running deficits, there are a number of substantive claims about the harms of deficit spending that deserve scrutiny. While some of these concerns turn out to be baseless, they are at least attempts to put something behind the generalized hysteria against deficit spending. Other concerns are much more substantive; and while they do not support arguments to eliminate federal deficits, they do serve the important function of helping to determine the possible limits of budget deficits and the tradeoffs that reducing budget deficits would imply.

The claim that the United States government will go "bankrupt" if it continues to run deficits is - despite its repetition by opponents of deficits - simply incorrect as a technical matter. ${ }^{39}$ All Treasury securities are denominated in U.S. dollars, which means that the promises embodied in Treasuries can be honored so long as the United States Treasury has dollars with which to pay its debts. Given that the central bank of the United States, the Federal Reserve System (more commonly known simply as the Fed), has the power to create dollars, it is not possible for the federal government ever to run out of dollars. Treasury securities will always be repaid.

The federal government's ability to create money means that there is no risk of default to a holder of a Treasury security. The borrowed money will be repaid, which is why financial institutions are willing to hold Treasuries as the equivalent of cash in their portfolios. ${ }^{40}$ Although such securities generally pay interest, the rates can be so low that the holders of Treasuries are investing their money for a virtually zero rate of return. This has been the case with very short-term Treasury securities for the last few years. The willingness of investors to hold Treasuries even without earning interest is testament to the confidence that investors have in the full faith and credit of the United States government. Investors are lending money to the government, and the only thing that they receive in return is the guarantee that the government will pay them back in full, in dollars.

It is possible, of course, for the Fed to create so much money that it creates inflation. The risk of inflation is heightened when the economy is operating at full capacity, as well as by very large increases in the amount of money in circulation. While this danger is always present in a modern

39 The discussion in this section draws extensively on Blinder, supra note 21.

40 It is possible that the money that is repaid will not have the same buying power as the money that the lender expected, as discussed below. Inflation risk is, however, distinct from default risk. 
economy, there is very little evidence that the Fed has ever come close to increasing the rate of inflation by creating too much money in response to the federal budget deficit. For example, during the Reagan administration, annual federal deficits were higher than at any time since World War II, yet the inflation rate fell from double-digit rates at the beginning of the 1980's and remained in the range of one to six percent for the rest of the decade. ${ }^{41}$ Similarly, outstanding federal debt has increased to sixty percent of GDP during the Great Recession years of 2008 through 2010, yet there is no evidence of an emerging problem with inflation. Not only has there been no hyper-inflation or even accelerating rates of inflation, but the inflation rate is near zero and trending downward. If anything, the bigger worry is not inflation but deflation.

Nonetheless, the risk of inflation does mean that there are prudential limits on deficit spending, with extraordinarily large deficits being a sure path to hyper-inflation. Unfortunately, the value (or even the range) of the upper limit on money growth is currently unknown. ${ }^{42}$ Any reasonable government would guard against such an outcome, but the U.S. experience suggests that there is minimal danger of even the current high levels of the budget deficit leading to excessive monetary growth and ultimately creating an increase in inflation.

\section{Deficits, Investment, and Future Prosperity}

While the risk of igniting inflation due to deficit spending is thankfully small, a more likely harm from deficit spending lies in a concept known as "crowding out." macroeconomic models is that, when a government buys or produces goods or services, it generally competes for resources with the private sector. When the government hires workers to build a dam, for example, those workers become unavailable to private contractors who might have used

41 See Bureau of Labor Statistics: Databases, Tables, \& Calculators By SuBJECT, http://data.bls.gov/PDQ/servlet/SurveyOutputServlet (last visited Apr. 15, 2011).

42 Needless to say, there is a large economic literature that attempts to identify the relationship between monetary expansion and inflation. The most that can currently be said is that monetary expansion can lead to inflation after a lag. On the other hand, the recent experience in which the Fed expanded one of its monetary control variables by historic margins, with no subsequent uptick in inflation, suggests that the relationship between monetary expansion and inflation is loose and imprecise. See, e.g., Neil H. Buchanan, How is Money Created? Debunking Some Myths About Recent Policies to Stabilize the Financial System and the Economy, FInDLAw, June 18, 2009, http://writ.news.findlaw.com/buchanan/ 20090618.html.

43 See Buchanan, Long-Term Deficits, supra note 27, at 311. 
them to build a factory. A government's spending decisions, therefore, can prevent private businesses from investing in productive capital projects.

The basic concern is that the federal government might reduce future living standards by reducing the private capital stock (factories, equipment, etc.) that will be available in future years to generate income for American business owners and their employees. This can happen when the federal government borrows money and then hires existing capital and workers to produce (either directly or indirectly) current consumption goods rather than capital goods for the future. ${ }^{44}$ The form of crowding out differs, depending upon whether deficits are financed with dollars borrowed from domestic or foreign sources; but no matter who finances the government's borrowing, the result under this theory is that the future incomes of American citizens will be lower than they would otherwise be. ${ }^{45}$

As discussed in Sec. III.C. below, the crowding out story is considerably more complicated than the brief description here suggests. At this point, however, the important lesson is that deficits today can be harmful tomorrow, if they cause the capital stock to be lower than it would otherwise be.

\section{Deficits and the Risks of a Financial Crisis}

Finally, it is possible that U.S. deficits could become so large for so long that financial markets collectively would lose confidence in the country's fiscal position. Indeed, it is precisely this scary possibility that many commentators have invoked in recent years as a reason to reduce the U.S. fiscal deficit. ${ }^{46}$ The idea is that there is no telling when the financial

44 It is also possible for the government's borrowing to crowd out private consumption, rather than private investment. If it does, then there will be no reduction in future productivity or living standards, because private consumption is merely being replaced by government consumption (consumption that will ultimately benefit private individuals). The mix of consumption will thus change, but there will be no crowding out of the capital stock.

45 If the government's borrowing reduces the actual capital stock, then the future output of the economy will be lower than otherwise. If the government borrows from foreign sources, thus allowing domestic saving to be used to build the capital stock to the levels that it otherwise would have reached, then the interest on the debt to foreigners will, in essence, drain the increased future income that such capital would create. This means, in essence, that borrowing from abroad allows the U.S. to accumulate more capital, but that the income from that capital does not benefit domestic citizens. This is the equivalent of crowding out the capital stock directly. See generally Blinder, supra note 21.

46 See, e.g., Committee for a Responsible Federal Budget, Debt Crisis Looming; Political and Market Risks Run Large, Comm. Responsible Fed. Budget Blog (May 6, 2010), http://crfb.org/blogs/debt-crisis-looming-political-and-market-risks-run-large [hereinafter "Debt Crisis Looming"] ("Yesterday, The Committee for a Responsible Federal 
markets will suddenly stop accepting trades in U.S. Treasury securities. Financial crises in other countries in the relatively recent past have been painful $^{47}$ and those crises arguably began without warning. If the U.S. government were to push its deficit to levels today and - much more important - in the future that would be viewed as unsustainable, then the resolution of that policy failure could be swift and harsh. ${ }^{48}$

Although it is true that a fiscal crisis could erupt at any time, with the financial markets forcing a sudden policy adjustment to prevent projected future imbalances from coming into being, ${ }^{49}$ the consequences of long-term fiscal imbalance could instead be felt gradually, with deficits reducing living standards over the space of years or decades. Large predicted deficits could - rather than bringing on a sudden crisis - result in rising interest rates on government debt, as financial investors begin to build the possibility of much higher inflation — and even a historically unprecedented U.S. default on its obligations ${ }^{50}$ — into the prices (and thus the rates of return) of Treasury securities.

Clearly, the gradual path is preferable to the sudden change. Just as clearly, however, no one knows how to predict whether, when, or how a fiscal crisis could emerge. One possible response to such uncertainty is to call for immediate action to prevent any such future crisis. ${ }^{51}$ It is not,

Budget hosted a chilling conference on 'What a Fiscal Crisis Would Look Like in the U.S.' An all-star group discussed: what a tipping point might be; how a crisis might unfold; and what policies would be best to avoid a crisis. There was a clear consensus in the room that without changes, a crisis [is] inevitable.").

47 The most prominent recent example is Greece. See, e.g., Norris, supra note 4 ("Much of the new international worry about government spending was prompted by the Greek debt crisis this year. It avoided default only with help from other European countries. That aid was conditioned on Greece agreeing to a strong austerity program, to be monitored by a group including representatives of the International Monetary Fund.").

48 Debt Crisis Looming, supra note 46 ("If investors lose confidence in the U.S., interest rates will soar, job creation will slow and the financial health of Americans will deteriorate.").

49 Norris, supra note 4 ("[I]n the late 1970s and early 1980s . . 'bond vigilantes' were reluctant to invest in United States Treasury securities because they feared runaway inflation. Their refusal drove up the interest rates the government had to pay on its borrowings and eventually led the Federal Reserve, under Paul A. Volcker, to wage war against inflation even if it meant choking off economic growth.”).

50 Although the discussion in Part II.B.1. showed that the United States government can always create the money necessary to pay its debts, it is at least possible to imagine that a government in the future could choose default over hyper-inflation for strategic reasons.

51 See, e.g., CRFB Holds Fortuitous Conference on Fiscal Crisis Scenarios, Comm. FOR A RESPONSIBLE FED. Budget, 2 (May 6, 2010) ("While it is impossible to precisely predict the 'tipping point' for a crisis, taking credible steps now is the best way to prevent 
however, possible to reduce the probability of a market crisis to zero. In the face of such uncertainty, one could simply call for action sooner rather than later, in the belief that waiting will only make matters worse. ${ }^{52}$

The risk of a crisis, however, hinges crucially on the psychology of markets looking forward for decades. No one doubts that the United States government could borrow trillions of dollars in any given year or set of years, without setting off a financial crisis, but if there is no long-term plan to manage the level of debt, then financial market participants could decide at any point that those future risks have become so worrisome that it is unwise to own U.S. government debt. ${ }^{53}$ The rush to sell that debt could be chaotic, with dire consequences for the U.S. and global economies.

This aspect of the problem - that it is the expected path of future borrowing that determines the likelihood of a financial crisis, rather than the size of the deficit this year (or even for the next ten or twenty years) leads some analysts to suggest that the problem for U.S. policymakers is to find a way to reassure financial market participants today that the debt problem will ultimately be brought under control. ${ }^{54}$ This "announcement effect" manage deficits and debt can deal with short-term problems by running deficits, safe in the knowledge that the financial markets expect deficits to return to sustainable levels after the short-term problems are under control.

While it might seem to be a simple matter of prudent management to reduce the risks of a fiscal crisis, it is essential to remember that it is anything but costless to reduce fiscal imbalances. These costs include, as discussed below, increases in current unemployment, reductions in current incomes, and general economic decline. ${ }^{56}$ Calls to reduce deficits as a way to avoid fiscal crises, therefore, imply an underlying judgment that the costs of deficit reduction will be lower than the probability-adjusted benefits of avoiding a financial crisis.

it.”), available at http://crfb.org/sites/default/files/CRFB_Holds_Fortuitous_Conference_0. pdf.

$52 I d$. at 1 ("The longer we wait to act, the greater the number of things that could set off a crisis.").

53 Debt Crisis Looming, supra note 46 (arguing that "the financial markets are based on faith and that the fiscal standing of the United States will drop when people lose faith that policymakers can control fiscal matters").

54 Id. ("The key is to make a commitment to a credible plan now.").

55 Committee for a Responsible Federal Budget, Announcing the "Announcement Effect Club," Comm. Responsible Fed. Budget Blog (Jan. 14, 2010), http://crfb.org/blogs/ announcing-announcement-effect-club.

56 Robert Eisner, The Great Deficit Scares: The Federal Budget, Trade, and SOCIAL SECURITY 3-28, 57-58 (1997). 
If the justification for enacting restrictive fiscal policy now is to reduce the likelihood of a fiscal crisis, however, then we must at least have some way of knowing how much we can reduce that likelihood by taking action now. Moreover, if participants in the financial markets were really convinced that the current fiscal path was (or were on the brink of becoming) unsustainable, there should be evidence that things are moving in the wrong direction. Yet that is simply not happening. Indeed, despite repeated warnings from anti-deficit commentators that a U.S. financial crisis is inevitable, interest rates have fallen this year. "[F] or now, the financial markets seem to fear recession and deflation much more than they fear deficit spending., ${ }^{, 58}$

Even so, what we are currently experiencing might be a brief calm before the storm. We might, after all, be only moments away from the onset of a crisis. Of course, that is always possible, no matter the situation. False Cassandras are not difficult to find, in any situation. Moreover, even if we knew when financial traders might decide that the government's long-term budget situation looks excessively risky, there is no way to know what a government must do to convince doubtful financial traders that it will take future actions that will solve the problems that have been predicted.

A government could announce, for example, a budget plan that shows long-term sustainability, but financial traders could doubt that various elements of that plan will be enacted and sustained. Even a government that ran short-term annual surpluses, allowing the government to pay down debt, could discover to its surprise that it has not done enough to please financial traders, if those traders decide as a group that the government's fiscal situation might reverse itself at some point. Just as there is no way of knowing when a crisis might come, there is no way of knowing how to prevent a crisis from occurring or how to satisfy the people who might bring the crisis upon us. ${ }^{59}$ There is, in the end, no way to predict what will satisfy the psychology of a large group of financial traders.

57 Norris, supra note 4 ("It would be disastrous if either [the United States or the United Kingdom] got to the point that investors abandoned it, or even drove up interest rates sharply by scaling back their support. But precisely the opposite has happened this year.”).

58 Id.; see also Paul Krugman, Appeasing the Bond Gods, N.Y. Times, Aug. 19, 2010, http://www.nytimes.com/2010/08/20/opinion/20krugman.html?_r=1\&ref=paulkrugman ("But the argument [that we must appease bond vigilantes] has become even stranger recently, as it has become clear that investors aren't worried about deficits; they're worried about stagnation and deflation. And they've been signaling that concern by driving interest rates on the debt of major economies lower, not higher. On Thursday, the rate on 10-year U.S. bonds was only 2.58 percent.").

59 See Krugman, supra note 58 (ridiculing the idea that "the bond vigilantes may be invisible, but they must be feared all the same"). 
As it stands, therefore, no one knows how to assess the likelihood of a financial crisis at any particular moment, much less how much that likelihood changes in response to specific policy changes. The most that we can say is that fiscal cutbacks would probably reduce the likelihood of a fiscal crisis by some amount. ${ }^{60}$ That, however, is hardly sufficient to guide any responsible policy decisions to reduce budget deficits (through cuts in social programs, Medicare, Social Security, or anything else). Even though it seems entirely plausible that most of those who somberly call for immediate sacrifice in the name of avoiding a fiscal crisis do so in good faith, therefore, there is a difference between good intentions and complete analysis.

Consider an analogy: increasing the height of a levee by one foot will reduce the likelihood of a flood, but unless we know how to measure the reduction in that likelihood, then we are not in a position to decide whether to undertake the necessary costs of building up the flood wall. Arguing that another foot will reduce the odds of catastrophe simply misses the larger point, because the same logic would lead to calls to add three feet, six feet, or fifty feet. Counseling "prudence" can sound very good when discussed out of context, but that is no guide for policy.

Policy makers should, of course, constantly monitor the situation for signs of a possible crisis, and they should support efforts to expand our knowledge of how fiscal crises come about. As it stands, however, the argument that we should make immediate or long-term spending cuts (or tax increases) in order to prevent a possible fiscal crisis cannot be a meaningful guide to calibrating actual changes in policy.

These shortcomings do not mean that the government can simply ignore long-term concerns, of course, but it is important to bear in mind that the threat of a financial crisis can be constantly invoked by those who wish, as an a priori matter, to force the government to adopt more restrictive fiscal policies.

Budget deficits, therefore, have the potential to cause both short-term and long-term damage to an economy. Any government would want to manage those risks prudently. Doing so, however, requires that it take into account the costs of adopting more restrictive fiscal policies. Those costs are discussed below, after a brief discussion of how the government might set targets for its annual borrowing. 


\section{Deficit Targets}

The key question facing any government budgeter is how to determine what the appropriate relationship should be, if any, between revenues and expenditures. If there were no reason to think about them together, then it would be possible simply to determine how much money to spend on roads, armies, pollution control, unemployment benefits, cancer research, copier paper, and so on - and separately to determine how much money to raise from taxes on estates, cigarettes, income, real property, sugary drinks, gambling, consumption, pollution, and any other possible targets of taxation. Even if there were no reason to worry about the balance or imbalance between spending and revenues, there would still be reasons not to spend money on wasteful or foolish projects, just as there would still be reasons to impose taxes (such as a desire to discourage smoking), even if revenues were not needed to fund the government. In such a world, however, the difference between expenditures and revenues would be a mere residual, not interesting as a matter of policy.

In the world in which we live, of course, there are limits on how far out of balance a government's expenditures and revenues can be. In the extreme, if the government were to choose never to raise money through any means other than borrowing, its revenues would equal zero, and there would never be any money available to pay back lenders except by borrowing from other lenders. This is unsustainable, which means that there must be some limit to how much the government can borrow in the aggregate.

In addition to technical limits on the ability of a national government to borrow money, there are also prudential limits. Even though, as explained below, it is possible to borrow large amounts of money in a sustainable way, there might be undesirable consequences from doing so that could overwhelm any positive effects of taxing less than one spends.

Therefore, the central issue of public finance is to determine the best combination of revenues and expenditures, taking into account the effects of deficits and surpluses on the economy's current and longer-range performance. ${ }^{61}$ While intuition and conventional wisdom often suggest that the government cannot and should not borrow money, at least not for long, that is definitively not what economic theory teaches us. In fact, there are several ways to define "balance" in the government's finances, each of which carries a different technical meaning, as well as a different implication for taxing and spending policy.

\footnotetext{
61 See generally Jonathan Gruber, Public Finance \& Public Policy (3rd ed. 2010).
} 


\section{Balanced Budgets}

The term "balanced budget" is bandied about quite loosely in political discussion, usually invoked as the only truly responsible target for federal budgetary policy. Taken seriously, this would mean that the federal government would be required to raise exactly as much money in taxes each year as it spends, at least within a (presumably very small) margin for error. The case for balanced annual budgets is frequently based on analogies to a family's finances, with the notion being that a responsible family must pay its bills, and so must a responsible government. ${ }^{62}$

There are, however, several serious issues that would flow from adopting a balanced budget target, beginning with the question of the proper time period over which balance must occur. As discussed above, the U.S. federal deficit is usually expressed as an annual measure, but it can be measured over any period of time, from as little as one day up to any length of time that one likes (including an infinite time horizon). ${ }^{63}$ Even if one believes that the budget should be balanced in the sense that revenues must equal expenditures, therefore, there is no reason why that balance must be achieved each year, as opposed to each month, decade, or century.

More fundamentally, the problem with balanced budgets as a target for policy is that they do not address the problem that is most often attributed to government deficits. That is, if a government should not owe money to anyone, then an annually balanced budget will only achieve that goal if the government began with no debt. With U.S. debt held by the public set to exceed ten trillion dollars by the time this article has been published, however, an annually balanced budget would merely lock in place the aggregate amount of federal debt that exists at the beginning of the new budget balancing regime. Even though such a policy might please its adherents by at least not adding to the debt, the existing debt would remain unpaid. Therefore, if it is overall debt that is bad, and not merely annual deficits, then a government that currently owes money to anyone must not only raise enough money to pay for its current expenditures, but it must also collect enough money to pay down the existing debt.

Even that strategy, however, leaves open the enormous question of how quickly to reduce overall indebtedness. Given that tax increases and

62 See, e.g., Robert Hurt Wins Endorsements from the Register and Bee, News and Advance, and Richmond Times-Dispatch, RoBertHurtForCONGRESS.COM, Oct. 24, 2010, http://www.roberthurtforcongress.com/2010/10/robert-hurt-wins-endorsements-from-theregister-and-bee-news-and-advance-and-richmond-times-dispatch/.

63 See Buchanan, Long-Term Deficits, supra note 27 (critiquing a proposal to measure the net present value of all future spending and revenues into the infinite future). 
reductions in spending tend to shrink the economy (at least in the short run), ${ }^{64}$ a government that wishes to reduce its overall debt must balance that desire against the danger of creating (or worsening) a recession or depression. Given current debt levels, efforts to pay down the entire debt in large chunks would be economically disastrous. Even if the economy were not already facing high unemployment and the possibility of a second round of economic decline, and even if the annual deficit were already at zero, the prospect of finding even a relatively modest sum like $\$ 300$ billion each year - which would allow the federal government to pay down the total federal debt over several decades - would be quite difficult politically. And as discussed later, this fiscal contraction would put downward pressure on the economy and upward pressure on unemployment, not just in the first year but in every year of the government's efforts to wring an extra $\$ 300$ billion out of the economy to pay down federal debt.

In short, proposals to reduce deficits - much less to reduce or erase all outstanding government debt - must be evaluated in terms of their tradeoffs. As we reduce deficits and debt, we need to understand why we are doing so, in order to know whether the benefits justify the costs of fiscal contraction. While the discussion to this point has simply taken the desire to reduce deficits and/or debt as a given, it is important to examine arguments in favor of deficit reduction that go beyond simple-minded beliefs that deficits and debt are per se bad. As the discussion below will demonstrate, all such arguments result not in policies to eliminate government deficits and debt but in policies for limiting deficits and debt. That is, even the strongest arguments against deficit spending will, if taken seriously, result in deficits and debt continuing into the indefinite future.

\section{Percentage Targets and the Debt-to-Income Ratio}

Beyond simple-minded attempts to set the annual deficit to zero, there are several more sophisticated ways to determine a deficit target. Many economists refer to an annual limit on the deficit of 3\% of GDP; for example, President Obama's outgoing budget advisor argued late last year that "in 2015, 2016, 2017, we need to get to something around 3 percent of the economy so that debt is no longer rising as a share of the economy." 65

The idea, therefore, is to run an annual deficit that will add to the debt, but not to do so in a way that increases the ratio of overall national debt to GDP. One of President George W. Bush's chief economic advisors, N.

64 See supra Part III.B.

65 Mike Dorning, Orszag Seeks Budget Deficit of 3 Percent of GDP in Six Years, BLOOMBERG, Nov. 17, 2009. 
Gregory Mankiw, a conservative economist who has returned to the Economics Department at Harvard University, also endorses the constant debt-to-GDP ratio as a target: "[E]ven in the long run, a balanced budget is too strict a standard. Because of technological progress, population growth and inflation, the nation's income and tax base grows over time. If the government's debts grow at or below that pace, servicing the debt will not become a major problem." 66 The government can, therefore, "run budget deficits in perpetuity, as long as they are not too large." 67

There are two difficulties even with this much more reasonable standard, however. First, the 3\% target is entirely arbitrary and is not a good guide for long-term deficits. ${ }^{68}$ Even though that specific target is officially the limit for all members of the European Union, ${ }^{69}$ there is no reason to believe that that number will keep the debt-to-GDP ratio constant. ${ }^{70}$ Indeed, if GDP were to rise by 5\% annually (which would be the result of targeted real growth of $3 \%$ and an inflation target of $2 \%$ ), then the debt could also grow by $5 \%$ without increasing the debt-to-GDP ratio. Attempts to meet an annual 3\% target, therefore, would only coincidentally succeed in keeping the debt-to-GDP ratio constant.

More fundamentally, there is no reason to believe that the current ratio of national debt to GDP is the "right" percentage. Yet an effort to keep the debt-to-GDP ratio constant would, if successful, enshrine the current arbitrary level as a policy ideal. If the recent increase in deficits was really harmful, then should we not try to return to the level of debt-to-GDP that existed before the recession began? Or, as discussed above, why not go to zero? If an annual balanced budget is "too strict," 71 however, then we certainly could not run the annual surpluses necessary to pay down the national debt.

This would suggest that we might be able to find a level of the debt-toGDP ratio that is too high, to set an upper limit on federal borrowing. Some recent work comparing debt levels and economic experiences crossnationally suggests that a debt-to-GDP ratio of $90 \%$ is the point at which the average country grows more slowly. ${ }^{72}$ Some analysts have seized upon

\footnotetext{
66 N. Gregory Mankiw, What's Sustainable About This Budget?, N.Y. TIMES, Feb. 14, 2010.

$67 I d$

68 Luigi L. Pasinetti, The Myth (or Folly) of the 3\% Deficit/GDP Maastricht 'Parameter', 22 CAMB. J. ECON. 103, 103 (1998).

69 Id.

70 Id.

71 Mankiw, supra note 66.

72 Carmen Reinhart \& Ken Rogoff, Growth in a Time of Debt 22 (Nat'l Bureau of
} 
this as yet another reason to be scared about the U.S. fiscal situation, because (by some measures) the U.S. debt-to-GDP ratio could pass $90 \%$ next year. ${ }^{73}$

This is, at least, a start in trying to understand the appropriate debt-toGDP ratio. Even so, it is the only study of its kind, comparing countries around the world. One economist, for example, noted "the ability ... of some advanced countries to manage debt burdens as high as 250 percent of GDP." 74 Moreover, there is no way to know whether the causality runs from high debt to low growth, or low growth to high debt. ${ }^{75}$

In short, there is no good answer to the question of how high the deficit can be, either in a given year or over the long term. Rather than fighting over whether the deficit is at the "right" level, therefore, the more sensible approach is to ask on an ongoing basis whether any particular change in the deficit - through either changes in taxes or spending — is justified on the basis of its contribution to the economy's health and to people's well-being. As discussed below, there are both short-run and long-run policies that will meet that criterion. We need to put in place a system of governance that does not forsake those policies in the mistaken belief that the deficit simply must be reduced.

\section{GOOD DEFICITS IN THE SHORT RUN: FIGHTING RECESSIONS}

Even some of the most adamant opponents of deficits concede that there is such a thing as a "good deficit." deficits are acceptable in the short run, if the economy is weak. Although even this basic wisdom has been drowned out in the current political atmosphere, it must be remembered that this point of view is absolutely the standard position among macroeconomists. ${ }^{77}$ While one can argue about

Econ. Research, Working Paper No. 15,639, 2010).

73 Committee for a Responsible Federal Budget, The 90 Percent Debt-to-GDP Threshold and CBO's New Debt Estimates, Comm. Responsible Fed. Budget Blog (Mar. 9,2010 ) ("[S]ometime this decade we will reach a point where our debt is sufficiently high to slow growth in a significant way.").

74 Paul Krugman, Debt and Transfiguration, The Conscience OF A Liberal (Mar. 12, 2010), http://krugman.blogs.nytimes.com/2010/03/12/debt-and-transfiguration/.

75 Id.

76 Good Deficit/Bad Deficit, Comm. For a Responsible Fed. Budget (Apr. 2009).

77 This is not to say that there are no voices raised in dissent against that standard position. Some economists who generally oppose active government involvement in economic stabilization continue to argue against the efficacy and wisdom of deficit spending, even in the face of the worst ongoing unemployment crisis since the Great Depression. See, e.g., Robert Barro, The Folly of Subsidizing Unemployment, WaLl ST. J., 
political aspects of deficit spending, such as whether delays of the legislative process will cause the deficit spending to be mistimed, there is very broad agreement that it is not only acceptable but wise to fight economic downturns with fiscal policy - especially if monetary policy cannot be counted on to push the economy back in the right direction. ${ }^{78}$

Because of that broad agreement, there is little need to go into excessive detail about the mechanisms by which short-run deficits work to improve a weak economy. This section, therefore, simply offers a brief summary of how budget deficits work during a recession. Because the case for long-run deficits is somewhat less well-known (though not, ultimately, more economically controversial) the next section will discuss the case for long-run deficits in a somewhat more painstaking fashion.

\section{A. Weak Economies Need Help to Be Brought Back to Life}

When an economy is in a recession, which has been the situation in the United States (and most other countries) from 2008 through the date of this

Aug. 30, 2010 (professor in Harvard's Economics Department arguing that, "[i]n general, the [Obama] administration has been too focused on expanding government, redistributing more from rich to poor, and stimulating aggregate demand"); Michael J. Boskin, Why the Spending Stimulus Failed, Wall ST. J., Dec. 1, 2010 (former chief economist to the first President Bush, now professor in Stanford's Economics Department summarizing some studies challenging the standard view of deficit spending during recessions - but favoring tax cuts, which can also increase aggregate demand — and concluding that "[t]hese empirical studies leave many leading economists dubious about the ability of government spending to boost the economy in the short run"); Alberto Alesina \& Silvia Ardagna, Large Changes in Fiscal Policy: Taxes Versus Spending (Nat'l Bureau of Econ. Research, Working Paper No. 15438, 2009) (describing cross-national study of economically advanced countries' uses of fiscal stimulus, claiming to find evidence that "spending cuts adopted to reduce deficits have been associated with economic expansions rather than recessions"); Alberto Alesina, Tax Cuts vs. Deficits: The Evidence Is In, Wall St. J., Sep. 15, 2010 ("How can spending cuts be expansionary? First, they signal that tax increases will not occur in the future, or that if they do they will be smaller."). But see Paul Krugman, Expansionary Austerity?, The COnSCIEnCE OF A LiBeral (Aug. 20, 2010), http://krugman.blogs. nytimes.com/2010/08/20/expansionary-austerity/ (critiquing the arguments in Alesina and Ardagna, and Alesina, and concluding: "Here's a comprehensive list of [cases where austerity led to growth]: Ireland 1987”). See also Arjun Jayadev \& Mike Konczal, THE Roosevelt Inst., The Boom Not The Slump: The Right Time For Austerity (Aug. 23, 2010), http://www.rooseveltinstitute.org/sites/all/files/not_the_time_for_austerity.pdf (criticizing the claims in Alesina and Ardagna, concluding "that there is little evidence provided by [Alesina and Ardagna] that cutting the federal deficit in the short-term, under the conditions the United States currently faces, would improve the country's prospects. It may even make the United States' situation far worse").

78 See infra Part III.B. 
writing, the elements that might provide strength to an economy all begin to move in the wrong direction, enhancing the negative effects of the recession in a vicious cycle of decline. There is not, in other words, a reliable method by which one can expect the economy to turn around, other than simply waiting and hoping that the economy will hit bottom and turn around on its own.

The four major sectors of the economy - the sources of spending that provide businesses with their reason for being, allowing them to hire workers - are: consumers who buy goods and services, businesses that buy capital equipment from other businesses, governments that both consume and invest, and foreign buyers of the nation's exports. The three nongovernmental sectors, however, all have completely rational reasons during a recession to make decisions that will make the economy as a whole worse off.

When consumers see that the economy is weakening, they worry that they might lose their jobs, so even the people whose consumption is not directly reduced by having been laid off are nonetheless wise to cut back their consumption spending. This, in turn, gives businesses reason to lay off still more workers, since the goods or services that companies currently offer for sale are no longer being sold. The newly laid-off workers are thus forced to retrench, and the news that there have been yet more layoffs makes the remaining workers even more reluctant to spend.

Because businesses see the economy weakening, furthermore, they have no reason to invest in capital equipment, new technology, or anything else that would allow a business to expand. There is no need for new investment, because the existing capital stock is more than sufficient to produce the smaller amount of output that can be sold under depressed economic conditions.

Exports could be a lifeline for an economy, allowing a country to sell its goods to foreigners who might still be spending. ${ }^{79}$ If a recession affects a large number of countries, however, there are fewer and fewer places to find people who can buy one's goods. Each country that is in recession, moreover, is motivated to try to export its way back to prosperity. Since it is literally impossible for every country to import less and export more at the same time, the use of the export sector to save the economy is only possible for a few lucky countries.

Only government spending remains. If the government refuses to spend to fight the recession, the recession will continue, and perhaps worsen.

79 See, e.g., John Murphy, Dear 44: Economic Lifeline, Politico, Oct. 13, 2008, http:// www.politico.com/news/stories/1008/14469.html. 
Moreover, if the government insists on increasing taxes whenever it increases spending, any positive impact of the spending is all but eliminated. ${ }^{80}$ Only a direct increase in the deficit has a hope of turning the economy around, and only then if the change in the deficit puts money into the hands of people who are likely to spend it. ${ }^{81}$

\section{B. Possible Economic Damage from Reducing Deficits}

In short, only government policy can swim against the tides of a weak economy. When the government perversely cuts back spending during a recession, of course, that only makes matters worse. Moreover, even when the economy is not in a recession, cutting government spending can turn things in the wrong direction.

Imagine, for example, that the U.S. government reduced its spending in a year by $\$ 300$ billion, or about $2 \%$ of GDP. ${ }^{82}$ This would reduce the size of the economy, at least in the immediate term, because (as described above) government spending is one of the four major categories that make up GDP. Reductions in the government's spending reduce the incomes of the people and businesses who would have received that spending in exchange for work performed, goods delivered, and so on.

Moreover, everything now works in the opposite direction from that described above, when the government increases spending during a recession. ${ }^{83}$ When people and companies lose income, they in turn reduce their spending (and, in the case of businesses, hiring), which is the classic "multiplier effect" of fiscal policy — so called because a one dollar reduction in spending by the federal government sets in a motion a chain of

80 As a technical matter, the "balanced-budget multiplier" — the multiple by which GDP increases when both spending and taxes go up by the same amount - is generally a positive number. This means that "pay as you go" rules do not entirely neuter expansionary fiscal policies, but they drastically reduce their effectiveness.

81 Tax cuts for people whose basic needs are already being met - people, in other words, who have relatively high incomes — are thus not particularly stimulative to the economy. Having the government itself do the spending most directly puts money into the economy, because doing so does not rely upon an individual's decision about whether to spend the money. Businesses that sell their wares to the government, in turn, then have an incentive to begin to hire more workers. See the discussion on the estimates of the impact of various types of spending and tax cuts, infra note 85 .

82 Three hundred billion dollars is equal to 2\% of 2010's nearly \$15 trillion GDP. Cong. Budget Office, The Budget and Economic Outlook: An Update, (Aug. 2010), http://cbo.gov/ftpdocs/117xx/doc11705/08-18-Update.pdf, at xiv Summ. Tbl. 2 (showing forecast for GDP in 2010 of $\$ 14,804$ billion).

83 See supra Part III.A. 
events that results in more than one dollar of GDP being lost to the economy. ${ }^{84}$ The size of the government spending multiplier continues to be the subject of extensive empirical investigation, with one recent estimate suggesting that a one percent increase in government spending leads to more than a $1.5 \%$ increase in GDP about a year later, ${ }^{85}$ and a more recent estimate of various types of government spending showing that the multiplier ranges from as low as 1.13 to as high as $1.74{ }^{86}$ If the highest number is accurate, that would mean that a $2 \%$ reduction in government spending would lead to a $3.5 \%$ decline in GDP. ${ }^{87}$

To err on the side of caution, however, assume that there is no multiplier effect at all, that is, that GDP shrinks by exactly as much as the federal government cuts its spending in a given year, assuming (counterintuitively and counter-factually) that private actors who lose incomes because of reduced federal spending choose not to change their behavior, negating any possible ripple effect of cutbacks. The hypothesized $2 \%$ cut in spending would then shrink GDP by only $2 \%$, rather than $3.5 \% .^{88}$ According to a well-known empirical regularity called "Okun's Law," this would lead to an increase in the unemployment rate of roughly $1 \% .{ }^{89}$ If the economy had started in a period of full-employment and broad prosperity, with the unemployment rate at $4 \%$, the spending cut would have put over one million people out of work, raising the unemployment rate to $5 \%$ or

84 See N. Gregory Mankiw, Macroeconomics 262-64 (4th ed. 2000).

85 See Christina Romer \& Jared Bernstein, The Job Impact of the American Reinvestment and Recovery Plan, app. 1, at 12 (Jan. 9, 2009), available at http://www.economy.com/mark-zandi/documents/The_Job_Impact_of_the_American_ Recovery_and_Reinvestment_Plan.pdf. A tax increase will have a smaller multiplier, because taxes do not show up directly in GDP. A tax increase, therefore, will only reduce GDP if it causes spending reductions by people or businesses. If it does, those reductions will also spill over into further spending cuts, as those who receive lower incomes after their employers and customers cut back on spending do likewise. If the tax increase does not cause an initial reduction in spending, however, there will be nothing to multiply, and there will be no reduction in GDP. See id. (showing that the tax multiplier plateaus just below a value of 1 , meaning that a $1 \%$ of GDP cut in taxes will lead to almost a $1 \%$ increase in GDP).

86 Perspectives on the U.S. Economy Hearing Before H. Comm. on the Budget, 111th Cong. 7 (2010) (statement of Mark Zandi, Chief Economist, Moody's Analytics) [hereinafter Testimony of Mark Zandi].

87 See id.

88 See id.

89 "Okun's Law" holds, as a rough approximation, that a $1 \%$ decrease (increase) in GDP is associated with a $2-2.5 \%$ decrease (increase) in unemployment. See MANKIW, supra note 84 , at 36 . 
more $^{90}$

However, the current economic situation is unique: "Under Okun's Law, a formula for the relationship between output and unemployment described by the 1960s-era White House economist Arthur Okun, the jobless rate at the end of 2009 would have been around 8.3 percent instead of 10 percent." $"$ If the historical relationship between lost GDP and job losses has gotten worse, then attempts to cut the deficit can impose an even larger long-term cost on the economy and the nation's citizens.

The short-term costs of deficit reduction can thus be severe, especially because they are concentrated on a small group of people rather than spread throughout the economy. ${ }^{92}$ The harms imposed on a small, vulnerable group can also have long-lasting effects, because the people thus affected can suffer losses from extended bouts of unemployment that are difficult to reverse, if they can be reversed at all. These consequences of unemployment include suicides and other acts of violence; ${ }^{93}$ but they also include the loss of skills and health that accompany being laid off from one's job. ${ }^{94}$

Of course, it is possible for monetary policy to offset some or all of this effect, with decreases in interest rates creating economic stimulus to offset the fiscal contraction. The ability of monetary policymakers to deal with this problem, however, is significantly less than perfect. The larger the fiscal contraction, the larger must be the offsetting monetary stimulus. There is a time lag between the onset of the monetary stimulus and its impact on the economy, with real harms continuing until the positive impact of the decreased interest rates is felt. ${ }^{95}$ Moreover, depending upon how low interest rates are at the beginning of the process, monetary policymakers might well reach the limit of their ability to offset the fiscal decline. During the 2008-2009 period, for example, interest rates were

90 See Testimony of Mark Zandi, supra note 86, at 7.

91 John Harwood, Mystery for White House: Where Did the Jobs Go?, THE CAUCUS (Jul. 19, 2010), http://thecaucus.blogs.nytimes.com/2010/07/19/mystery-for-white-housewhere-did-the-jobs-go/?scp=1\&sq=\%22 welcome $\% 20$ as $\% 20$ it $\% 20$ is $\% 22 \&$ st $=$ cse.

92 A $1 \%$ across-the-board decline in income would hurt everyone a little bit, whereas a $100 \%$ decline in income for $1 \%$ of the work force would hurt over one million people severely.

93 T.A. Blakely, S.C.D. Collings \& J. Atkinson, Unemployment and Suicide. Evidence for a Causal Association?, 57 J. Epidemiol Community HeAlth 594, 594 (2003) (finding that "[b]eing unemployed was associated with a twofold to threefold increased relative risk of death by suicide, compared with being employed").

94 See Claudia Rowe, Those Who've Lost Careers Face Deep Psychological Stress, The Seattle Times, Nov. 20, 2010.

95 Andrew B. Abel \& Ben S. Bernanke, Macroeconomics 541-42 (5th ed. 2005). 
already so low that there was virtually no room to engage in traditional interest rate cuts to fight the ever-deepening recession. ${ }^{96}$

The point here is not to discuss all of the nuances of fiscal and monetary policy options - issues well beyond the focus of this paper but to note that there are very serious consequences of fiscal cutbacks. In addition to the indirect effects discussed above, it must also be remembered that cuts in government spending result in people losing the benefit of whatever spending has been cut. ${ }^{97}$ If a person was receiving governmentprovided job training, for example, then a budget cut to eliminate spending on that program will not only harm the economy by putting the job counselors into the ranks of the unemployed, but the beneficiary of that training will also be worse off. ${ }^{98}$ When a state government loses a federal grant to cover school costs, teachers are laid off, and children are forced into larger classes with less contact with the teachers who remain. ${ }^{99}$ Moreover, if the cutback takes the form of reducing federal spending on long-term investments (such as education), the consequences will be much more long-lasting. ${ }^{100}$

In short, discussions of "fiscal responsibility" are incomplete if they focus only on the reductions in the deficit that accompany spending cuts. Cutting spending also means reducing someone's income, and while some cuts can be "no-brainers" because they eliminate pure waste, ${ }^{101}$ the persistence of many spending programs is at least partly explained by the fact that such programs provide value to someone. Even when a program

96 It is true that the Fed has engaged in some nontraditional methods to stimulate the economy even when its target interest rate had been reduced to near zero, but those creative methods were also quite controversial.

97 See, e.g., Cuts Hurt NY Environment Department, Officials Say, CBS N.Y., Nov. 18, 2010, http://newyork.cbslocal.com/2010/11/18/cuts-hurt-ny-environment-department officials-say/ (explaining how budget and staffing cuts keep the New York Department of Environmental Conservation from performing its job); see also Lisa Singleton-Rickman, School Funding: What's Next?, Times Daily, Nov. 25, 2010, http://www.timesdaily.com/ article/20101125/news/101129871 ?Title=School-funding-What-s-next.

98 See Singleton-Rickman, supra note 97 (discussing the effects of cutting government spending on education, "I'm afraid it will be larger classes and teachers losing out on professional development - the kind of things that have helped make our system strong").

99 See id.

100 See infra Part IV (regarding the difference between government consumption and government investment).

101 See, e.g., Eric Lichtblau, Lobbying Imperils Overhaul of Student Loans, N.Y. TIMES, Feb. 4, 2010 (discussing the 2010 change in the federal student loan program, which ended the subsidy program that gave money to lenders to make loans that were risk-free, because they were guaranteed by the federal government). 
does not do so, however, there is at least a short-term loss to the economy for virtually every cut in spending, because the spending cuts result in people losing their jobs. That affects not just the laid off workers, but their families and communities, and the broader economy as well.

\section{Deficits Use Resources That Would Otherwise Lie Idle}

As described earlier in this article, the most important and plausible harm from running deficits is "crowding out," which is the process by which the government's deficit claims resources that might have been used by private businesses to expand their productive capacity. ${ }^{102}$ If the economy is operating below capacity, however, there is a temporary free lunch, in that the government can hire workers and machines that would otherwise remain idle. $^{103}$

Because of this, the private sector is not disadvantaged by the government's additional involvement in the economy, and indeed the new government workers are enabled to buy items from private companies that they otherwise would not have been able to afford. This can encourage private firms to increase spending on productive plant and equipment, creating a virtuous cycle that can help to end the downturn. The process by which government spending can increase private investment is known as "Crowding In."104

Since there is no tradeoff between government and private spending during a downturn, therefore, crowding out is only a relevant concern during periods of prosperity. ${ }^{105}$

\section{The Increase in Overall Debt During Recessions is Sustainable}

The final aspect of running deficits in the short run is whether notwithstanding all of the other benefits that deficits have in mitigating recessions - the resulting increases in the national debt are a matter of concern. The short answer is that they are not. As noted above, there is wide agreement that a constant ratio of national debt to GDP represents a

102 See supra Part II.

103 See Benjamin M. Friedman, Crowding Out or Crowding In? Economic Consequences of Financing Government Deficits, Brookings PAPERS ON ECON. ACTIVITY 593, 596-97 (1978).

104 See id.; Neil H. Buchanan, The Effects of the Fiscal Deficit on the Composition of U.S. GDP: An Analysis of Disaggregated Data, in Improving the Global Economy 133

(Paul Davidson \& Jan A. Kregel eds., 1997).

105 See Friedman, supra note 103. 
sustainable and fiscally responsible situation. ${ }^{106}$ Short-run deficits, by definition, increase national debt by a finite amount. If it takes, say, an increase in the debt-to-GDP ratio of $10 \%$ to end a recession, the debt after the recession is over will not continue to rise (at least, not because of antirecessionary spending).

Moreover, a healthy economy will return to a higher level of GDP, thus lowering the debt-to-GDP ratio below where it would have been had the economy continued to languish. In addition, because GDP grows annually in a healthy economy, any increase in the overall debt due to antirecessionary spending will shrink as a percentage of GDP, as the economy grows in the future. ${ }^{107}$

In sum, an ailing economy needs "good deficits" in the form of higher government spending. Failing to provide such stimulus needlessly extends the misery of a recession, and it does nothing to improve the long-term health of the economy.

\section{GOOD DEFICITS IN THE LONG RUN: ENHANCING GROWTH}

An essential responsibility of conscientious governance is to determine the likely effects of our current spending decisions on future well-being. The most important of these long-term effects, however, are not to be found in measurements of budget deficits but rather in the nature of the spending projects that we undertake. Some government projects help only people living today, others will provide benefits only to people in the future, and still others will be a boon to the present and the future alike. For legal and policy analysts, therefore, the most important issue in assessing any government policy is not whether it increases the deficit, but whether the policy is in a meaningful sense "worth it.",

The concept of public investment is not difficult to understand. The wisest way to spend money is not necessarily to spend as little as possible. The question of what the government buys is just as important as how much

106 See supra Part II.

107 Mindy R. Levit, Cong. Research Serv., The Federal Debt: An Analysis of Movements From World War II to the PRESENT, 13 n.36 (Sept. 17, 2010) (“'In the 1990s, debt held by the public as a percentage of GDP declined during deficit years because GDP grew faster than the debt itself thereby decreasing the ratio. Because of this, declines in the debt-to-GDP ratio are more common historically than budget surpluses.").

108 Joe Minarik, Good Debt, Bad Debt, Huffington Post, July 29, 2010, http:// www.huffingtonpost.com/joe-minarik/good-debt-and-bad-debt_b_664046.html (concluding that public investment should be paid for up-front, but noting that certain types of investments are more productive than others, "Public investment is essential. . . Public debt can be a necessary evil.”). 
it buys, or whether to run a deficit. Cutting spending on productive investments in the name of fiscal responsibility is simply unwise. As one analyst argued early in the 2008 presidential election season: "For all their recent talk about wasteful spending, none of the Republican [presidential] hopefuls have offered specifics about what they would ax. But in the past, their targets have been programs that foster better health, education and infrastructure. Those are precisely the investments we need for economic vitality." "109 Indeed, the Bush administration - which at least claimed to disapprove of government spending programs - was willing to spend money on projects that would enhance future prosperity. ${ }^{110}$

Moreover, the government's budget itself — not just general economic prosperity - is often harmed by short-term thinking that treats budget cuts as inherently good, even when such cuts are especially foolish:

Preventing cancer, or treating it early, is a lot less expensive than treating advanced cancer. So what did this president do? $\mathrm{He}$ proposed a cut in the program of $\$ 1.4$ million ..., which would mean that 4,000 fewer women would have access to early detection. This makes no sense. In human terms, it is cruel. From a budget standpoint, it's self-defeating ... "It won't save money. . . . You don't save money by not diagnosing cancer early. You end up spending more money because anyone who develops cancer will get into the health care system and they will be treated. And the cost at that point will be a lot more. The logic here is very simple: the later you diagnose cancer of the breast or cervix, the more expensive it is to the country.",111

The case for running deficits in the long run, or when the economy is not in a recession, is not as simple as the case for stimulus spending. Even so, there is ultimately very little disagreement among economists that it is possible to have the government improve the economy by investing in capital that will improve living standards in the long run. ${ }^{112}$ The concept

109 Editorial, Deficit Demagogues, N.Y.TIMES, Mar. 21, 2006, at A16.

110 Elisabeth Bumiller \& Adam Nagourney, Bush, Resetting Agenda, Says U.S. Must Cut Reliance on Oil; Funds for Science, N.Y. TIMES, Feb. 1, 2006, at A1 ("[In his 2006 State of the Union address, President Bush] proposed a substantial increase in financing for basic science research, called for training 70,000 new high school Advanced Placement teachers and recruiting 30,000 math and science professionals into the nation's classrooms.").

111 Bob Herbert, Illogical Cutbacks on Cancer, N.Y. TiMES, Mar. 20, 2006, at A23 (quoting Dr. Harold Freeman, a physician specializing in the prevention and treatment of cancer).

112 Marco Bassetto with Thomas J. Sargent, Politics and Efficiency of Separating 
has been well known to economists for decades, ${ }^{113}$ and it has been implemented in other countries at various times, as well as by many U.S. state governments. ${ }^{114}$ The problem, as discussed below, is not with the concept but with the politics. First, however, it is useful to describe how a government can run deficits into the indefinite future in a way that enhances the well-being of its current and future citizens.

\section{A. The Tradeoff Between Government and Business Spending: Theory}

If the government buys or produces goods and services (when the economy is not in a recession), it will displace some kinds of private activity. ${ }^{115}$ An essential question for policy makers (though hardly the only question) is whether swapping private spending for public spending will increase or decrease living standards in the future.

Answering that question requires two steps. First, we need to know whether the government spending and the private spending that are being traded off would be used to purchase investment goods, like factories and machinery that will last a long time and can be used to increase future productivity, or consumption goods, which have no long-term benefit. Second, if both entities would invest rather than consume, we must compare the payoffs of the respective investments.

Consider the first part of that analysis. If the government would spend its money on investment goods, while the private spending would have been used to purchase consumption goods, the situation is simple: the government's spending will surely increase future living standards, relative to what they would have been if the money had been spent on private consumption. Similarly, if the choice is between private investment and public consumption, future growth obviously will be higher if the spending is done by private entities. Imagine, for example, that the government were to throw a large party by hiring people who would otherwise be working as computer programmers and construction workers. In that case, the future productive capacity of the economy would be reduced. ${ }^{116}$

Capital and Ordinary Government Budgets, 121 Q. J. OF ECON. 1167 (Nov. 2006) (showing an increase in economic efficiency when the government finances investments with increases in public debt).

113 Id. at 1169 ("John Maynard Keynes long . . . advocated the rule.”).

114 Id. at 1167.

115 See Friedman, supra note 103, at 635 ("Under either transactions crowding out or portfolio crowding out, income increases because each dollar of government spending replaces a smaller, though still strictly positive, amount of private investment.").

116 If the government throws its party by hiring the people who would have worked at a privately-funded party, then future production is unaffected. 
The interesting situation is the second part of the analysis, where both the government and the private sector would spend money on productive investments. In that situation, long-term growth is maximized when the money is spent on the investment project that has a higher payoff, i.e. a higher rate of return. If the government has on tap a project that could return $10 \%$ annually on investment, while a private firm wishes to finance a project that could pay $5 \%$, then the government's spending is a better way to raise the living standards of future generations.

Determining the expected rate of return on investment projects is, of course, anything but an exact science, as discussed at some length in the next section. As a very rough proxy, however, we can assume that private firms have conducted their own financial analyses and will engage in investment projects that pay a higher rate of return than the cost of borrowing for the firm. If a firm can borrow at $3 \%$ and invest at $5 \%$, that is a profitable proposition. Firms are thus believed to forgo those projects with low rates of return, relative to the interest rates at which they borrow.

The returns on potential government investments are not as easy to determine. ${ }^{117}$ If we had perfect information, we could simply maximize the output available to future generations by allowing the government to engage in investment projects with rates of return that exceed market interest rates. If our goal is to maximize future growth, the ideal stance for the government is thus not to reduce spending to the lowest possible level but to spend only on projects that have rates of return that exceed the interest rate for private borrowing. ${ }^{118}$

117 See generally Kenneth J. Arrow \& Robert C. Lind, Uncertainty and the Evaluation of Public Investment Decisions, 60 AM. ECON. REv. 364, 364-78 (1970) (discussing options for determining which public investments to undertake given the uncertainty of returns on investment).

118 This, however, still leaves open the question of why we must maximize the capital stock that we pass on to our heirs. Given that economic growth is generally on an upward trend, why is it necessary to give our wealthy grandchildren even greater wealth? The broad (within the economics profession as well as among politicians) silence on this question is notable, to say the least. The unspoken assumption is quite blunt: we must not do anything to reduce the capital stock that we bequeath to our children and grandchildren. Perhaps it is time to question that assumption more aggressively. See Neil H. Buchanan, What Do We Owe Future Generations?, 77 GeO. WASH. L. REv. 1237, 1250-57 (2009). (Moreover, although the subject for a different article, it is equally important to account for the "intergenerational unfairness" created by problems such as environmental damage.) Notwithstanding that concern, the present analysis adopts the conventional approach in attempting to maximize future growth for the benefit of future people. 


\section{B. Capital Budgeting, Growth Budgeting, and Future Well-Being}

The fundamental accounting concept of "capital budgeting" separates government expenditures into two categories: purchases of goods and services for current consumption that provide no long-term payoff ("operating expenditures"), and purchases of productive capital goods that do generate long-term payoffs ("capital expenditures"). ${ }^{119}$ The capital budget thus accounts for items whose benefits are longer-lasting and can be expected to produce economic activity and growth in the future that is greater than would otherwise happen. ${ }^{120}$ One rough estimate of the fraction of federal spending that can be categorized as capital expenditures is $25 \%$. $^{121}$ With federal spending at $\$ 3$ trillion in fiscal $2009,{ }^{122}$ that rough guide would mean that $\$ 750$ billion of that year's spending by the federal government went toward items that are likely to pay for themselves over the long run. ${ }^{123}$

It is also possible, as discussed below, to expand the range of possible public investments that would count as capital expenditures to include those that do not produce physical infrastructure but that nevertheless provide long-term economic benefits. Adding these items - such as spending on basic research, health care, nutrition, etc. - to the more narrowly defined capital budget, I use the term "growth budgeting" to describe a modified capital budgeting system through which the government can identify available long-term investments that could benefit posterity.

Capital budgeting as an accounting concept is so fundamental that it must be as old as accounting itself. Any sensible decision maker would want to know whether spending is being undertaken for immediate gratification or for long-term benefit. By accounting convention, publicly held corporations must separate operating and capital expenditures. Indeed, most "profitable" corporations would not be viewed as such if they were prevented from segregating their capital expenditures from their operating expenditures, since even the most profitable corporations borrow money

119 Jack Rabin, 1 Encyclopedia of Public Administration and Public Policy, 155 (Merker Dekker, Inc. 2003).

120 Many capital projects are likely to bring with them the requirement of at least a minimal level of maintenance expenditures. Depreciation of the existing capital stock and maintenance expenditures are thus netted out of the capital account.

121 See Buchanan, Debt, Deficits, and Fiscal, supra note 23.

122 Congressional Budget Office, CBO's Baseline Budget Projections (Apr. 4, 2008), http://cbo.gov/ftpdocs/90xx/doc9015/Selected_Tables.pdf.

123 See id. 
every year (that is, they run "deficits"). ${ }^{124}$ Similarly, the vast majority of state and local governments use capital budgeting. ${ }^{125}$ The requirement that most U.S. state governments balance their budgets is, indeed, not what it might seem, because a state can still borrow money for capital spending even if it does not have the tax revenue to pay for the capital items in the year in which they are purchased. ${ }^{126}$

Almost all large organizations in the world, including governments, have adopted some form of a capital budget, with the U.S. federal government standing out for its failure to adopt (and to be disciplined by) a capital accounting system. ${ }^{127}$ It is odd, therefore, that the federal government would not use capital budgeting. This failure has led to a great deal of consternation among budget analysts, concern that becomes especially pronounced when assessing the federal government's options in the face of large-scale crises such as the damage due to Hurricanes Katrina and Rita on the Gulf Coast in 2005, the oil spill in the Gulf of Mexico in 2010 , and more generally the government's failure to invest systematically in future productivity. ${ }^{128}$

124 Mark Mizruchi \& Linda Stearns, A Longitudinal Study of Borrowing By Large American Corporations, 39 ADMIN. SCI. Q. 118, 138 (1994) ("Many of a firm's most critical decisions, including plant expansion, development of new technologies, entering new product lines, and acquisitions of other firms, require the use of external financing. ... All corporations borrow money.").

125 RABIN, supra note 119, at 155 ("Eighty-four percent of state governments separate capital expenditures from operating expenditures, $40 \%$ of counties separate capital expenditures from operating expenditures, and $71 \%$ of cities separate capital expenditures from operating expenditures.").

126 See id. ("State and local governments use capital budgets because it improves decision efficiency since capital assets can be financed either by revenue raised currently (taxes, charges, grants, etc.) or by borrowing on the promise to repay from future revenues. If operating and capital expenditures are combined, capital assets appear more expensive relative to operating expenditures, even though they will be used over a number of years. Capital budgets are financed, but not necessarily balanced; operating budgets are balanced.").

127 Id. ("The federal government does not have a full-scale capital budgeting process. Funding for most federal capital assets is provided in annual appropriations under discretionary caps.”).

128 Sherle R. Schwenninger, A Capital Budget for Public Investment, NEw AM., 61, available at http://www.newamerica.net/files/NAF_10big_Ideas_10.pdf ("Indeed, the federal budget does not even officially distinguish between spending on productivityenhancing investment and spending on current consumption. As a result, the federal government currently does not adequately fund investment in our nation's physical infrastructure of knowledge capital upon which a more productive economy rests."); see also Michael Moynihan, Investing in Our Common Future: U.S. Infrastructure, NDN, Nov. 13, 2007, http://ndn.org/paper/2007/us-infrastructure. 
After natural disasters strike, policy makers are generally quick to respond to calls for rebuilding, knowing that this type of spending is quite different from other types of government spending projects, yet they are also mindful that such rebuilding projects can themselves veer from being necessary and productive spending into becoming opportunities for wasteful and even corruption-riddled spending. What is missing is a mechanism by which we could ensure that a capital account would not present too great a temptation for political actors, who - it seems likely would attempt to move many dubious items from the operating budget onto the capital budget, thus obscuring the wasteful nature of some government spending during such rebuilding efforts. ${ }^{129}$

More deeply, the concern is that it might not be possible to identify a principled approach to capital budgeting that would reliably separate true investments from the remainder of government spending. The general problem, therefore, is in determining the relative costs and benefits of various potential government spending programs. Unfortunately, "[i]n the world of infrastructure, cost-benefit analysis is still a science of the future." ${ }^{130}$ Any attempt to draw lines, even in a world without crass political opportunism, could thus fail to achieve the goal of identifying those spending projects - and only those spending projects - that contribute to the long-run growth of the U.S. economy and that therefore can be financed through deficit spending without compromising the longterm prosperity of the American people. ${ }^{131}$

The arguments against having the federal government adopt capital budgeting are thus ultimately prudential, based on the belief that it is simply unwise to trust Congress with such a powerful tool for justifying deficit spending. ${ }^{132}$ With a capital budget available, the argument goes, any silly

129 See Moynihan, supra note 128 (“A National Infrastructure Bank would give public authorities means to capitalize federal investment in new infrastructure projects. It would also create a new center of knowledge and expertise on infrastructure with the ability to intermediate between the public and investors. On the other hand, concentrating responsibility for federal infrastructure finance in a bank might reduce the flexibility of some agencies (and the authority of some congressional committee chairmen).”).

130 David Leonhardt, A Stimulus With Merit, And Misses, N.Y. TIMES, Jan. 28, 2009, at B1.

131 June E. O'Neill, Dir. Cong. Budget Office, on Capital Budgeting Before the President's Commission to Study Capital Budgeting (April 24, 1998), http://www. cbo.gov/doc.cfm?index=440\&type $=0$ [hereinafter 1998 CBO Study] ("Substituting annual depreciation for full acquisition cost in the budget, therefore, would displace an objective measure with a subjective one, whose imprecise character would make it a convenient target for manipulation and distortion.").

132 See id. 
expenditure can be slipped into the federal budget and camouflaged as capital spending. The entire process, this argument continues, would be open to abuse and gamesmanship. ${ }^{133}$ Indeed, former President Clinton drew fire from the nation's English teachers (who, it must be noted, are not typically a force in national politics) when he attempted to describe some spending policies as "investments," taking third place in the 1993 Doublespeak Awards because of his use of "the word 'investment' as a substitute for the word 'spending' in his rhetoric on economic policy.",

While it is certainly possible to over-use the word "investment," the English teachers simply had their accounting wrong. The choice is not between spending and investment, but between investment spending and consumption spending. If we view government as having to choose between the two, then our goal should not be to prevent politicians from using the term "investment," but rather to ensure that they use it correctly.

This is an especially apt example of the aphorism that we should not let the perfect be the enemy of the good. That is, we should not allow the difficulties of creating a complete system that could flawlessly classify every investment project on the capital account (and all other projects on the operating account) to prevent us from identifying the relatively easy cases where a spending project is almost certainly an investment in future prosperity. Because perfection is impossible, any type of real-world capital accounting system should certainly have as a default position that any spending project is presumptively on the operating account. Yet there should be a mechanism to allow items to be moved onto a capital account. As discussed below, that mechanism could include simple legislative action on an item-by-item basis, or it could involve the harnessing of technical expertise through either an independent agency (for example, a budget agency modeled along the lines of the Federal Reserve) or through quasijudicial decision-making in an adversarial process. ${ }^{135}$

\section{Capital Budgeting, the Golden Rule, and Growth Budgeting}

Because it is so difficult to determine whether expenditures will have long-term payoffs to the economy, it is a common short-hand to view government purchases of physical items (buildings, roads, etc.) as investments (and thus on the capital account) and its other purchases as

133 See, e.g., Karen Pennar, Beware of Accounting Magic Tricks, Mr. Clinton, Bus. WK., Jan. 18, 1993, at 55.

134 Jan Ackerman, Forked Tongues Prevail on High; Pentagon Gets Annual Doublespeak Award from Teachers Group, PitT. Post-GAzETte, Nov. 22, 1993, at B-1.

135 See infra Part III.B. 
consumption (and thus operating expenditures). ${ }^{136}$ While the logic of this is appealing, it omits some of the most important items on which the government spends money.

For example, when the government funds basic research, it does not buy a physical item but wishes to buy something that will provide longterm returns to the economy. Spending on all levels of education, on medical care, and on nutrition programs all offer the promise of long-term payoffs that could exceed borrowing costs. ${ }^{137}$

The key is not to maximize the purchase of physical infrastructure but to choose the physical and intangible investments that will provide the greatest benefit to future citizens. This goes beyond simply arguing in favor of adopting a system of capital budgeting. It also suggests that even balancing an operating budget is not sufficient.

Balancing the operating account while borrowing to finance items on the capital account, sometimes called the Golden Rule of Budgeting, ${ }^{138}$ actually allows the government to waste resources if it is able to raise the taxes to do so. This should be unacceptable, because it would represent a direct transfer from the politically voiceless to those who benefit from the wasteful spending. Instead, the government's decisions should always include considerations of whether those decisions are helpful to the current and future health of the economy.

Because of the common tendency to refer only to physical capital when discussing capital budgeting, I have coined the term "growth budgeting" to make clear that the purpose is to choose those expenditures that will increase future growth, not to spend money on "capital" only in its narrower physical meaning.

\section{Some Examples: Investing in Children}

A good example of the kind of analysis that should be brought into a

136 In the U.S. federal government's National Income and Product Accounts, government spending is divided into consumption expenditures and gross investment. See Bruce E. Baker \& Pamela A. Kelly, A Primer on BEA's Government Accounts, SuRv. OF Current Bus., Mar. 2008, at 32 ("Gross investment is the value of investment in structures, equipment, and software.").

137 Indeed, even short of these intangible items, a decision rule that simply puts the label of "capital investment" on anything made with concrete can impoverish the future. "[A sensible spending plan would] help cover the budget shortfalls of public transit systems, instead of simply allocating another $\$ 30$ billion for the construction of new highways." Leonhardt, supra note 130.

138 See also Bassetto, supra note 112; cf. Malcolm Sawyer, On Budget Deficits and Capital Expenditures 3 (The Jerome Levy Econ. Inst., Working Paper No. 208, 1997). 
Growth Budgeting regime concerns expenditures on early childhood education programs. A number of careful studies have been undertaken over the last several decades to determine whether spending on the education of very young children pays dividends to society. ${ }^{139}$ The theory is that catching children (especially at-risk children) early and giving them extensive help in learning how to learn will increase the likelihood of success throughout their lives, reducing the costs of special education, prisons, etc. $^{140}$

The question is whether those investments actually pay off, and by how much. An assessment of several such studies shows that estimated rates of return on investments in early childhood education are extremely high, with estimated benefit/cost ratios (in present value terms) ranging from 2.36 in one study to 17.1 in another. ${ }^{141}$ Because a ratio of 1.0 implies that (properly measured) costs equal (properly measured) benefits, a ratio of 2.36 means that every dollar spent results in $\$ 2.36$ of benefits, while a ratio of 17.1 means that every dollar spent results in $\$ 17.10$ in benefits. ${ }^{142}$ Passing up these future benefits in the name of safeguarding the future (through deficit reduction) is nonsensical.

Other researchers have found equally promising results for investments in young children. For example, a summary of studies by two economists showed that "[o]n productivity grounds alone, it appears to make sound business sense to invest in young children from disadvantaged environments. An accumulating body of evidence suggests that early childhood interventions are much more effective than remedies that attempt to compensate for early neglect later in life." 143

Similarly, recent research has shown that, even after children enter the

139 See e.g., Jim SaXton, Joint Econ. Comm., Investment in Education: Private AND Public RETURNS (2010), http://www.house.gov/jec/educ.htm (concluding that investment in education provides enormous social and economic benefit and noting " $[\mathrm{t}] \mathrm{h}$ ere is a strong consensus among economists that formal education is an important determinant of individual earnings as well as economic growth").

140 Julia B. Isaacs, Cost-Effective Investments in Children, in BUDGETING FOR NAtional Priorities 1, 4 (The Brookings Institution ed., 2007) (“A large research literature has documented many positive effects of preschool programs, including greater school readiness and higher educational attainment, as well as reduced criminal activity and increased employment as an adolescent and adult.”).

141 Id. at 6 tbl. 2

142 See id.

143 James J. Heckman \& Dimitriy V. Masterov, The Productivity Argument for Investing in Young Children, 1 (Invest in Kids Working Grp., Comm. for Econ. Dev., Working Paper No. 5, 2004), available at http://www.ced.org/images/library/reports/ education/early_education/ivk/summary_heckman.pdf. 
school system, the benefits of their earliest experiences show up later in life:

Students who had learned much more in kindergarten were more likely to go to college than students with otherwise similar backgrounds. Students who learned more were also less likely to become single parents. As adults, they were more likely to be saving for retirement. Perhaps most striking, they were earning more. $^{144}$

The results showed that "a standout kindergarten teacher is worth about $\$ 320,000$ a year. That's the present value of the additional money that a full class of students can expect to earn over their careers."145 Moreover, this analysis focuses only on the economic returns to education, meaning that it does not "take into account social gains, like better health and less crime." 146

In short, by using existing techniques, it is possible to determine the long-term payoff from at least some public spending. In the case of early childhood education, the returns vastly exceed the costs, making such spending a good investment in future wealth (to say nothing of the human impact of better educational outcomes). The question is how to use that information in a way that can improve the budgeting process, without opening up the budget to abuse.

\section{E. The Advantages of Piecemeal Decision-Making}

The standard analysis of capital budgeting, as in the Golden Rule approach noted above, involves an assessment of the entire government budget's effect on economic growth. ${ }^{147} \mathrm{We}$ assess whether the government's investment spending will pay net dividends, and we are thus able to say whether aggregate public investment is above or below the optimal level. As a theoretical exercise, this approach is sensible, but for actual policy making, this approach biases decisions against public spending by tying the fate of clearly advantageous investments to our ability to determine the payoffs of all other possible investments. Since that has never been accomplished, the exercise might wrongly be abandoned in

144 David Leonhardt, The Case for \$320,000 Kindergarten Teachers, N.Y. TIMES, July 27, 2010

$145 I d$

$146 I d$.

147 See supra Part IV. 
the belief that the information required to make any smart investments is unavailable.

We can avoid this tendency by changing the focus of analysis from whether we are spending the optimal total amount on public investments to whether any particular project has long-term payoffs. Given that we know, for example, that early childhood education programs have a high rate of return, there is no reason to hold spending on such a sure winner hostage to our limited knowledge about other budget items. Such a piecemeal approach thus allows us to move items onto the Growth Budget on a caseby-case basis, leaving some potentially valuable projects unfunded, but at least including in the Growth Budget those projects about which we have reason to feel especially confident. Being wrong or uncertain about one policy need not cause us to be wrong when estimating the effects of other policies.

\section{FisCAL DisCIPLINE THROUGH AGENCY ACTION}

Given the great promise of a Growth Budget, it is necessary to consider the possible ways in which such a new approach to federal budget accounting could go awry. Perhaps the most obvious problem, as noted above, is the temptation for politicians to move unworthy items onto the Growth Budget for reasons having nothing to do with the merits of the projects at hand. Any system that implicitly makes some projects less expensive than others - by allowing them to be financed through borrowing rather than taxing - invites predictable abuses of the political process, fed by lobbying, localized interests, and so on. ${ }^{148}$

The ultimate goal of this exercise is to allow the federal government to proceed to make at least some of the easier calls in its spending decisions, without continually being stymied by the impossibility of creating an ideal accounting system. Before turning to that concern, however, it is important to acknowledge some possible objections to this proposal that are beyond the framework of the present analysis.

\section{A. Rejecting the Growth Budget Out of Hand}

As a theoretical matter, the general notion of capital budgeting (and the specific proposal here for adopting a Growth Budget) might seem almost too simple. It is, after all, nothing more than an applied version of costbenefit analysis. As such, it is subject to the same concerns that apply to all cost-benefit analyses, including whether we have taken all costs and

148 See 1998 CBO Study, supra note 131 and accompanying text. 
benefits into account, the quality of our data, and the framework for turning those data into estimated payoffs. Still, it might appear that one could not reasonably oppose the adoption of a Growth Budget from a theoretical standpoint, leaving open for discussion only what to include in a Growth Budget and how to determine what will be included in that budget.

There are, however, three possible reasons that one could reject out of hand the need to consider adopting any kind of capital budgeting. First, one could believe as an empirical matter that there are simply no examples of any kind of government spending that has long-term payoffs. While this is logically the same thing as saying that an item-by-item analysis will result in no projects being added to the Growth Budget, one might start from the position that there is a nonrebuttable presumption that government spending is always inferior to private spending.

Second, one could believe that some proposed government programs might indeed offer long-term payoffs but that those financial benefits are offset by the very fact that funding such programs would cause the government to grow and intrude further into people's lives. ${ }^{149}$ In short, the cost of public investment is always greater than the benefit of public investment because the growth of government is simply too much of a threat to personal freedom.

The third objection that one might raise to abandoning the current system and adopting the Growth Budget is that the risks and costs of such a new accounting system are simply too high. ${ }^{150}$ Even if there are some projects that could be funded without abusing personal freedoms and with high promised returns, the costs and risks of switching to a new and untested system make it not worth the experiment. The creation of any new federal agencies and procedures might well impose long-term costs on society that would overwhelm any projected gains from projects on the Growth Budget.

The analysis in this article does not directly engage with these three objections. The presumptions here are that there might be some spending projects that only the government can or will undertake, that those projects might be superior in terms of creating economic growth than the private spending (if any) that they indirectly replace, that there is nothing unique to

149 See Minarik, supra note 108 (“There is no 'good' public debt.”).

150 See 1998 CBO Study, supra note 131 ("The threat to budgetary control from adding an ambiguous budgetary category, labeled capital, increases with the need to measure depreciation for the various forms of federal capital expenditure. Depreciation schedules cannot avoid being arbitrary. Examples abound of investments with significant residual value after complete depreciation, and of others that have a positive book value but have become worthless because of technological or economic change."). 
such government programs that makes them a threat to freedom or democracy, and that the administrative costs of adopting and running the Growth Budget are presumptively smaller than the net returns on the projects that would otherwise not be financed. All but one of those presumptions is ultimately subject to empirical verification, which is either implicit in the analysis here (such as the identification of early childhood education programs as high-payoff spending projects) or is beyond the scope of the present article. The untestable presumption, regarding the dangers of what is usually called Big Government, is a matter of political philosophy that is also outside the scope of this analysis.

In short, the analysis in this paper proceeds by setting aside potentially valid objections to the very idea of starting down the road to separating government spending into consumption and investment. Even for those who are willing to set aside those objections, however, several serious obstacles remain before one can confidently believe that the Growth Budget would improve our long-term economic prospects.

\section{B. Using and Abusing Capital Accounts}

The primitive nature of current budget practices is, to anyone with even a rudimentary knowledge of accounting principles, unsettling.

In the current system, the federal government sends money to states without any real effort to evaluate whether it will pay for worthy projects. States rarely do serious analyses of their own. They build new roads before fixing old ones. They don't consider whether those new roads will lead to faster traffic or simply more traffic. They spend millions of dollars on legislators' pet projects and hulking new sports stadiums. ${ }^{151}$

At best, we are inching toward a system with a few small attempts to bring rigor to the budgeting process. "At least one version of the [2009 stimulus] bill also sets aside $\$ 5.5$ billion to be awarded by the transportation secretary, supposedly on the merits of a project." ${ }^{, 152}$

The existing system, therefore, is ripe for improvement through the adoption of even the most minimally competent budgeting procedures. The legitimate concern, however, is that we can go too far in the other direction, by creating an opportunity to move spending into the Growth Budget without any reasonable checks on how that is done. While it hardly

151 Leonhardt, supra note 130.

152 Id. 
stretches the imagination to suspect that members of Congress do not always act in accordance with pure economic theory, it is simply not true that a capital budgeting process must automatically be an open cookie jar. Accounting standards have existed for decades and have been adapted to various types of government activities. ${ }^{153}$ Government and private entities do, of course, sometimes play at the edges of these rules, but the very fact that accounting-related mismanagement comes to light and is treated as a problem arises from the presumption that those rules are otherwise generally being followed. Even if enforcement is imperfect, there is no reason to presume that the system must necessarily be open to rampant abuse. Even an irregularly enforced speed limit will generally result in slower traffic than no speed limit at all.

Moreover, the current federal system effectively treats all expenditures as if they were operating expenses. ${ }^{154}$ While it is possible to adopt a capital or growth budget and then to implement it incorrectly, not to implement it guarantees that the government's budget is measured incorrectly. ${ }^{155}$ It also leads to poor policy choices. If the only goal is to balance the budget, cutting projects with valuable long-term payoffs looks just as good as cutting purely wasteful spending. It even becomes "desirable" to sell public assets at a loss, since any revenues proceeding from those sales reduce the annual deficit.

Separating government spending into investment and consumption, therefore, has at least two desirable effects. First, it would prevent policymakers from cutting programs that are likely to provide long-term benefits to the economy. For example, to prove their fiscal responsibility, the leadership of the House of Representatives several years ago wanted to cut funding for mass transit, because they "see transportation projects as one of the first ways to cut back the budget and reduce the deficit." 156

While it is plausible that some mass transit projects would not provide long-term payoffs, others surely would. For present purposes, the assertion is simply that there are likely to be some projects that would qualify for the

153 See generally Generally Accepted Accounting Principles, FED. ACCT. STANDARDS ADVISORY BD., http://www.fasab.gov/accepted.html (discussing accounting procedures for the U.S. federal government); Gov'T ACCT. STANDARDS BD., http://www.gasb.org/ (discussing accounting procedures for the U.S. state and local governments).

154 See RABIN, supra note 119, at 155.

155 See generally Moynihan, supra note 128 (advocating the creation of a National Infrastructure Bank that would allow public authorities to capitalize federal investment in new infrastructure projects).

156 Raymond Hernandez, Senate Panel Backs Transit Aid for New York, N.Y. Times, Feb. 5, 2004, at B7. 
Growth Budget, and it would thus be wise to identify them and to pay for them, even from borrowed funds. At the very least, it remains to be proven that the political gamesmanship that would exist under a system of capital budgeting would necessarily be worse for the economy than our current system.

The second advantage of adopting a capital budget for the federal government is that it would penetrate the category commonly known as "pork-barrel" spending. The operative definition currently seems to be that pork is anything that directly benefits a specific legislator's constituents: "Relatively little of the extra spending [in a 2007 supplemental budget request] is targeted to lawmakers' home districts - a precondition for labeling something pork." ${ }^{, 157}$ For example, the late Senator Robert Byrd (D., W. Va.), proudly described himself as the "Prince of Pork" for his ability to direct federal projects into his home state. ${ }^{158}$ Among his successes:

There are two Robert C. Byrd United States Courthouses, four Robert C. Byrd stretches of highway, freeway, expressway and drive, and a Robert C. Byrd Bridge. And two Robert C. Byrd Interchanges to reach these valuable amenities. There is the Robert C. Byrd Lifelong Learning Center, the Robert C. Byrd Hardwood Technology Center, the Robert C. Byrd Health and Wellness Center, and the Robert C. Byrd Institute for Advanced Flexible Manufacturing. ${ }^{159}$

Similarly, the advocacy group Citizens Against Government Waste makes a practice of itemizing what it views as "waste" in government spending projects. In one recent report, the group identified some of "the most egregious earmarks," including such items as \$94.1 million for "Levee work (California)," \$425 million for "Education grants for rural areas," \$4 million for "Office of Women's Health at Food and Drug Administration," $\$ 969.65$ million for "Influenza pandemic preparedness," and \$1.25 billion for "Public housing agencies." 160 While it is possible that each of those items is actually wasteful (either in their entirety or by being funded too

157 Editorial, Deadlines, War Money and Pork, N.Y. Times, Apr. 23, 2007, at A18.

158 Greg Moore, U.S. Senator Robert C. Byrd Dies at 92, W. VA. GAZETTE, June 28, 2010, http://wvgazette.com/News/201006280099 ("Byrd was perhaps best known for the way he funneled dozens of projects and millions of federal dollars to his home state, West Virginia. He earned the sobriquet 'the Prince of Pork' from some taxpayer groups - they meant it as an insult, but Byrd wore it as a badge of honor.").

159 Francis X. Clines, How Do West Virginians Spell Pork? It's B-Y-R-D, N.Y. Times, May 4, 2002, at A1.

160 Thomas Schatz, Pork Goes to War, N.Y. Times, Mar. 30, 2007, at A27. 
generously in light of their long-term payoff), at least their descriptions suggest projects that could be classified as capital spending projects. An essential goal in creating the Growth Budget would be to move beyond superficial labels and identify the valuable projects, to save them from a thoughtlessly wielded budget ax.

\section{Can Budget Abuses be Disciplined by the Political Process?}

Adopting a system of Growth Budgeting would open up a wide array of possible spending decisions that could be described as public investments. For any proposed spending program, it is at least plausible to imagine an argument that the economy will grow faster if that project is funded. (Such arguments would, however, be subject to the kind of costbenefit accounting discussed in this article.) It is, however, possible that the political process, for all its faults, will do a reasonably good job of determining when spending is worth it and when it is not. This seems more likely for some categories of spending than for others.

\section{Difficult Calls: War and Growth Budgeting}

For example, spending that is related to the military generally has much broader support than spending that benefits the poor and the socially marginalized. While there is a colorable argument that expenditures for carrying out wars should be subject to the same analysis that we apply to spending on bridges, schools, nutrition, and so on, the high stakes in wars make it difficult even to fathom a cost-benefit analysis that would satisfy broadly held notions of what should count as worthwhile military spending. Former Secretary of State Condoleezza Rice justified the cost of military operations in Iraq along such lines: "There have been plenty of markers that show that this is a country that is worth the investment, because once it emerges as a country that is a stabilising factor, you will have a very different kind of Middle East."

Such arguments may well be valid, as are even broader arguments that we must be willing to pay any price to defeat an enemy and protect our very way of life. ${ }^{162}$ As one economist put it: "When it comes to judging whether war is worth it, however, cost-benefit analysis is little more than educated

161 Rice Backs 'Worthwhile' War, BBC News, Dec. 22, 2006, http://news.bbc.co.uk/go/ $\mathrm{pr} / \mathrm{fr} /-/ 2 / \mathrm{hi} /$ middle_east/6202469.stm (emphasis added).

162 See, e.g., Winston Churchill, We Will Fight on the Beaches, June 4, 1940, http:// www.fiftiesweb.com/usa/winston-churchill-fight-beaches.htm ("We shall go on to the end, ... we shall defend our Island, whatever the cost may be.”). 
guessing by other means. But at least it provides a framework for where to put the guesses." 163

Determining the net costs of war is not merely intractable analytically, but, as noted above, it is the kind of decision that is virtually certain to be handled directly (if not necessarily well) by the political process. If we decide to go to war without raising taxes, then we are implicitly deciding that the war is a capital expenditure. If we decide to raise taxes to pay for war, then we are either saying that it is not worth it to finance the war through debt or that we are willing to sacrifice even more now, despite the benefits that fighting and winning the war will bestow on future generations.

Indeed, it seems likely that some types of spending are approved too frequently (in a cost-benefit sense) because of their political popularity. While troubling, that category of spending is irrelevant for the current analysis, because popular spending is already being undertaken. Growth budgeting, as envisioned here, is a process that opens up the possibility of justifying spending that would otherwise not be approved, and it does so only after passing muster on a cost-benefit basis. The Growth Budget should pave the way for approval of high-payoff projects that would not otherwise have been undertaken.

\section{Independent Analysts and Official Estimates}

The failure to finance projects that have highly promising payoffs might be a problem of information rather than a failure of governance. One could imagine that Congress might simply be acting in the dark, and if some light were to shine on the investment opportunities that it misses each year, it would readily fund those projects.

The evidence to date, however, suggests that there is no shortage of research available regarding a wide range of such missed opportunities. ${ }^{164}$ There appear to be many worthwhile investments that have been regularly ignored, ${ }^{165}$ which raises the question of why legislators are not acting on

163 Alan B. Krueger, The Cost of Invading Iraq: Imponderables Meet Uncertainties, N.Y. Times, Mar. 30, 2006, at C3.

164 See, e.g., William T. Dickens, et al., The Effects of Investing in Early Education on Economic Growth, Policy Brief \#153, The Brookings Institution, April 2006; see also Isaacs, note 140.

165 Elizabeth Kolbert, Uncomfortable Science, THE NEw YorKer, Nov. 22, 2010 (discussing Congress' failure to move forward with the Waxman-Markey bill and noting, "Not content merely to ignore the science, [Republicans] have decided to go after the scientists"). 
the available evidence. One possibility is that the sources of those analyses are of unknown quality and independence. In the cacophony of issue advocacy in the halls of government, it might simply be too timeconsuming and contentious to figure out which research reports can be believed and which should be ignored.

This raises the prospect that the government could clarify matters by designating an agency that would produce reports on the long-term payoffs of various investment projects, both by carrying out independent research and by assessing the research carried out by nongovernmental analysts. Congress could act on those pronouncements even if there were no obligation to do so.

To a certain degree, this is already done. The Congressional Budget Office $^{166}$ and the Office of Management and Budget ${ }^{167}$ provide budgetary analyses for Congress and the Executive branch, respectively, and statistical agencies within various cabinet departments provide useful assessments of government projects. ${ }^{168}$ Even if an official stamp of approval on budget analyses could overcome the credibility problem (so long as the budget analysts themselves maintain a reputation for independence and honesty), at the very least it would seem necessary to designate one agency as the source of official estimates of the payoffs of potential public investment projects.

If there were a credible government source that determined the most worthwhile spending projects, that agency could take on the role of providing a sort of public shaming function. An analogy would be to the Treasury Department's annual computation of "tax expenditures," 169 which purport to show how the government has used the tax system to provide the equivalent of direct spending on various politically favored items (such as

166 CBO Testimony Before the Joint Comm. on the Org. of Cong. of the U.S., 103rd Cong. 11 (statement of Robert D. Reischauer, Dir. Cong. Budget Office, 1993), available at http://www.cbo.gov/ftpdocs/103xx/doc10386/1993_06_10reischauertestimony.pdf ("One of CBO's most important functions is to keep track of all spending and revenue legislation considered each year, so that the Congress can know whether it is acting within the limits set by the annual budget resolutions.").

167 The Mission and Structure of the Office of Management and Budget, WhiteHouSE.GOv, http://www.whitehouse.gov/omb/organization_mission/ (explaining the primary functions of the Office of Management and Budget).

168 William F. Eddy, What Is The Statistical System?, NATIONALACADEMIES.ORG (May 8, 2009), available at http://www7.nationalacademies.org/cnstat/Eddy\%20Slides\%20May\% 208\%202009.pdf (providing an overview of the primary statistical agencies that issue data to the cabinet departments).

169 See discussion and official estimates reprinted in William A. Klein ET AL., Federal Income TaXation 9-11 (14th ed. 2006). 
owner-occupied housing, charitable contributions, etc.). ${ }^{170}$ If an official agency were to use the Growth Budget to expose the high-payoff items that Congress has failed to fund, it could potentially create some pressure to fund those projects.

Additional pressure in the right direction could come from requiring that official announcements of fiscal deficits be adjusted downward for the amount of public investment. Doing this would not directly require Congress to fund any specific items, but it would mean that when Congress approved an item that would be deemed public investment, the announced deficit would not rise.

Each of these ideas at least moves the process in the right direction, by providing information and incentives that would increase public investment. Nonetheless, there are stronger measures that could be used to make it even more likely that productive investments would not be overlooked.

\section{Administrative Procedures}

There are a number of possible ways to use administrative processes to bring some of the benefits of the Growth Budget to federal spending decisions. The discussion that follows assesses several possibilities and concludes that the best available approach would be to create a Growth Budgeting Board (GBB), which would be empowered to determine which spending projects would be included on a federal growth budget and would thus not be counted in official deficit estimates. The other possibilities also have their appealing features, as discussed below, but they ultimately seem less promising than something along the lines sketched out for the GBB.

\section{A Quasi-Judicial Process}

Perhaps the most far-reaching and detailed approach to assessing the investment potential of various spending programs would be to create a process modeled on administrative law courts. Under such a system, the federal government could set up "budget courts" that would be empowered to determine whether a spending project should be added to the Growth Budget. Such a system would have the advantages of any adversarial process, allowing proponents of a spending plan to try to prove that the project would provide long-term benefits, while opponents of the plan would attempt to disprove such claims.

170 Tax expenditure analysis has been the subject of intense criticism. See Clifford Fleming \& Robert Peroni, Nice Try, Joint Tax Committee, (2008) (unpublished manuscript) (on file with author). 
Although such a system draws on many of the best parts of the modern administrative state, the creation and administration of such a system presents challenges that should discourage even the most ardent advocate of the adversarial system. To begin, it is not clear who would have standing to argue in favor of or against any specific proposal. Presumably, members of Congress could argue on both sides, but there might well be instances in which no member of Congress would find it worthwhile to oppose a particular item's inclusion in the Growth Budget, as well as the likelihood of quid pro quos whereby members would agree not to challenge each other's favored projects. It would be possible to grant standing to interested parties who study these issues, such as the various government watchdog groups that currently issue public information about government spending and waste, but there is no obvious way to limit the pool of potential litigants in a principled way.

In addition to standing, these administrative law courts would need rules of evidence and standards of proof to apply in their decisions. Congress, in enabling legislation, could specify these rules up to a point, and there is at least some likelihood that a consensus of best practices would emerge relatively quickly in these cases. Even so, if there were more than one administrative law judge hearing these cases, there would be a distinct possibility of inconsistent decisions.

Ultimately, an administrative law approach to growth budgeting seems unwieldy and expensive. It is thus unnecessary to explore these and related technical issues, such as how judges would be selected for such a system, the standards and venue for appeals, etc. Suffice it to say that any system of this sort would be likely to founder on the administrative complexity involved. Because of its inherent complexity, moreover, the administrative law approach would also be likely to fail to provide timely decisions. If Congress needs decisions quickly, a quasi-judicial process seems the least appropriate way to proceed.

Despite the flaws of a system of administrative courts, such a system is useful to consider because of the light it sheds on the other possible approaches discussed below. Were it not for its high transaction costs (broadly defined), the administrative law approach would have much to recommend it. The more workable alternatives should at least offer the possibility of capturing some of the advantages that are gained from evidence-based decision-making by qualified decision makers.

\section{Blue-Ribbon Commissions}

At the opposite end of the spectrum from administrative courts, in 
terms of institutional complexity, are Congressionally mandated expert commissions. The federal government has previously set up, in addition to simple fact-finding commissions, expert commissions that provide Congress with reports that require legislative action. The most famous of these in recent memory was the commission that drew up a list of military bases that would be closed under a broad consolidation plan to reduce spending on facilities that had outlived their usefulness. ${ }^{171}$ The commission was not directly empowered to close any bases, but Congress agreed in advance that its proposals would be voted as a single slate. ${ }^{172}$ This was designed to get around the problem of special pleading, in which every member of Congress had an incentive to fight to keep open the facilities in her state or district, and no other member found it worthwhile to fight against a motivated colleague. ${ }^{173}$

The base-closing commission has generally been hailed as a success, and it certainly provides a model for possible action. ${ }^{174}$ Recently, a member of Congress proposed a similar type of commission to "look at the tax code and the array of entitlement programs and produce a set of recommendations ... to put them on a fiscally sustainable course." ${ }^{175}$ This proposal has not been enacted, but it suggests that there is concern that Congress's normal processes will never produce needed reforms of the tax code, Medicare, etc.

This type of commission, however, seems ill-suited to deal with the issues that motivate a call to adopt growth budgeting. The issues considered by the base-closing commission or the proposed tax and entitlements commission, even though they arise on a continuous basis, can be handled periodically. That is, while one could imagine having a base-closing

171 See Defense Base Closure and Realignment Commission, BRAC.GOv, http://www. brac.gov/About.html (last visited Apr. 12, 2011) (describing BRAC's function and most recent 2005 Commission Report).

172 See Fred Hiatt, Fixing the Budget In the Worst (But Only) Way, WASH. Post, Apr. 12, 2009 ("Recognizing that the Pentagon operated too many facilities but that no legislator would vote to close a base in his or her own district, Congress set up a Defense Base Closure and Realignment Commission (BRAC), which came up with a rational downsizing plan. Congress had to vote for the whole list or nothing at all; there could be no special pleading.").

173 See id.

174 The so-called Greenspan Commission, which created a plan to change the financing of Social Security in 1983, is another example of a commission that is widely thought to have been a success.

175 Editorial, The Everything Commission: Can Congress and the President Get the Fiscal House in Order - or Must that Job be Outsourced?, WASH. Post, June 13, 2006, at A20. 
commission that issued reports every year, it is also relatively harmless to have the commission do its work once and go out of existence until and unless Congress decides to go through the process again. A full-scale rewriting of the tax code could also be a one-time (or at least occasional) exercise.

By contrast, the annual budgeting process is always filled with decisions about whether some items could have long-term payoffs; so it would seem wise to create a system that is ongoing rather than ad hoc. If such a commission were to become a permanent part of the budget process, however, it would cease to be a "commission" in the sense in which that term is often used. ${ }^{176}$ Instead, it would become an administrative agency of the sort discussed below.

\section{The Fiscal Fed}

Where adjudicative processes are inappropriate, and where political decision-making is possibly tainted, agency decision-making based on professional expertise is often the best alternative. Congress could create a system for determining fiscal policy that is politically insulated, that draws on the best available knowledge, and that employs trained decision makers. Indeed, Congress did just that for monetary policy when it created the Federal Reserve System in 1913. ${ }^{177}$ Although the Fed's actions can be reversed through legislation - indeed, the Fed itself can be abolished by legislation - it has been delegated complete authority in determining monetary policy. ${ }^{178}$

It would be possible for Congress to do the same with fiscal policy, creating a so-called Fiscal Fed to take over policy-making with regarding to government spending and taxation. Using the Fed itself as a model, or developing an alternative, one could imagine a system in which Congress

176 Matthew Eric Glassman, Cong. Research Serv., Congressional Commissions: Overview, Structure, and Legislative Considerations, 2-4 (2008), available at http://assets.opencrs.com/rpts/R40076_20081219.pdf ("While no legal definition exists for what constitutes a 'congressional commission,' in this report a congressional commission is defined as a multi-member independent entity that (1) is established by Congress, (2) exists temporarily, (3) serves in an advisory capacity, (4) is appointed in part or whole by Members of Congress, and (5) reports to Congress.").

177 See generally Federal Reserve Act, 12 U.S.C. $\$ \S 221-522$ (1913) (establishing the federal reserve system); see also Gyung-Ho Jeong et al., Political Compromise and Bureaucratic Structure: The Political Origins of the Federal Reserve System, 52 J.L. \& ECON. 472, 476-82 (2009) (discussing the Federal Reserve's insulation from political influence).

178 See 12 U.S.C. $\S \S 221-522$. 
delegates its authority over fiscal policy to a board of experts. ${ }^{179}$ Such a move would remove from Congress's direct authority decisions that might better be handled by experts who are not worried about raising funds for their re-election campaigns.

The most obvious reason to suspect that Congress would never agree to create such an agency is that much of its power and influence derives from its power of the purse. If one goal of a Representative or a Senator is to be re-elected, and if the electoral system will continue to require fund-raising, it is easy to see why Congress would not want to create a Fiscal Fed. Moreover, even a legislator whose motives went beyond political survival could sincerely argue that decisions about taxing and spending should not be isolated from the political process. One could readily believe that the value of representative democracy would be seriously diluted if only noneconomic issues were the subject of direct congressional action.

\section{The Growth Budgeting Board (GBB)}

Fortunately, the advantages of agency decision-making can be harnessed for the purposes identified in this article without a wholesale abdication by Congress of its fiscal policy-making powers. A "miniature" Fiscal Fed, with responsibility only over identifying the short-run and longrun spending that can be financed by deficits, would still leave Congress with ample responsibilities in setting fiscal policy — determining the level and content of spending, the level of tax receipts, the design of the tax code, etc.

This mini-Fiscal Fed, which could be called the Growth Budgeting Board, could be empowered to carry out two basic functions: (1) to identify when short-run changes in government deficits can be designated as antirecessionary, allowing such deficits to be created for a limited period of time, and (2) to gather evidence regarding spending projects that might finance worthy long-term investments and that should be put on a growth budget. This centralized process would allow the board's members to make

179 The constitutionality of such a plan could be in doubt. Some argue, in fact, that the Fed itself was an unconstitutional delegation of authority. See, e.g., Ashvin Pandurangi, How Did A Single Unconstitutional Agency Become The Most Powerful Organization In America?, BusinessInsider, Nov. 7, 2010, http://www.businessinsider.com/fed-isunconstitutional-2010-11 ("The most powerful, influential economic policy-making institution in the country, the Federal Reserve ('Fed'), is an unelected body that is completely unaccountable to the people. Well, let's back up and start with the fact that this institution's very existence is most likely unconstitutional."); Bill Denman, THE AM. VIEW BLOG (Oct. 27, 2005), http://www.theamericanview.com/forums/showthread.php?t=299 (explaining why, in his view, the Federal Reserve Board is not constitutional). 
group decisions about whether financing a project through borrowing would be advantageous to future growth.

Congress has, in fact, already at least talked about creating some type of administrative agency to deal with a few aspects of annual budgeting decisions, including consideration of a so-called "infrastructure bank."

The [2009 stimulus] bill could create a small-scale version of an "infrastructure bank," a free-standing entity that could make more merit-based decisions than Congress does (an idea that Mr. Obama supports). The bill could also finance the creation of new state offices to conduct cost-benefit analyses. ${ }^{180}$

These discussions are apparently limited to infrastructure projects (which, as noted above, are only one sub-category of the universe of spending projects that could qualify for inclusion in the Growth Budget), but there is no reason why the concept could not be expanded.

If Congress were to create a Growth Budgeting Board, it would need to decide whether the proposed agency's decisions would be advisory or would become law (possibly subject to an override process), but the most important step is to provide some rationality to the system. If a member of Congress, an industry group, or a public advocacy organization wanted the GBB to move a spending program to the Growth Budget, they would have to provide some meaningful evidence that the project would actually pay off. "The current system is so inefficient that even a minimal amount of change would represent progress. If you want your project moved to the front of the line, you should have to come to Washington bearing hard data - not flimsy boosterism - about its economic and environmental benefits." 181

Perhaps the most important question in designing the GBB is the degree of certainty that it must find before determining that a spending item should be added to the Growth Budget. Should it use the fiscal equivalent of "beyond a reasonable doubt," or "more likely than not," or "clear and convincing evidence"? Because of the uncertainty associated with the state of the art in budget projections, and because there should be a presumption against allowing spending to be financed by borrowing, the standard should probably be set rather high - certainly high enough (say, a $75 \%$ or even a $90 \%$ probability) that we would generally not borrow to pay for items that do not justify their financing costs.

180 Leonhardt, supra note 130.

181 David Leonhardt, Piling Up Monuments of Waste, N.Y. Times, Nov. 19, 2008, at B1. 
Even with a strong presumption against categorizing a project as public investment, however, this would still be an improvement over the current situation. Some "low-hanging fruit," such as the early childhood education programs noted above, should easily clear any hurdle and be approved for the Growth Budget. Those easy decisions alone could more than justify the effort.

\section{E. Pre-Screening and Post Mortem Assessments}

An administrative decision-making process along the lines of the proposed Growth Budgeting Board would have the ability both to prescreen projects for possible inclusion in the Growth Budget (that is, to issue advisory opinions) and to assess after the fact whether projects had actually paid off. Pre-screening would enhance the prospects of funding promising projects, by making them look "less expensive" than if they were on the operating budget, meaning that Congress would not need to decide to, say, cut funds for cancer research in search of a balanced budget.

Having a list of pre-screened public investment projects would be particularly helpful when Congress needs to fund economic stimulus. During the debate in early 2009 over the economic stimulus bill, one concern was that it would take too long to approve some public investment projects and begin to spend the money. ${ }^{182}$ The GBB could include in its assessments of possible spending projects the time line of spending entailed by each project, allowing Congress to determine whether the project fits into a reasonable time line. More important, simply having such a list would mean that there would be projects that have already been reasonably vetted and have been screened for inclusion in the Growth Budget, giving decision-makers the ability to move up the starting date on such projects. This would naturally dovetail with the Board's duty to identify when shortrun spending projects can be justified as anti-recessionary.

Since part of the point of a growth budget is to determine whether we are spending money on projects with long-term payoffs or that provide only short-term consumption, the GBB could assess retrospectively whether its earlier decisions (positive and negative) have been correct. If an item was not approved for the Growth Budget but was funded anyway and turned out to produce growth, it would be possible to update the national accounts later to reflect that fact. Similarly, mistakes in the opposite direction would need

$182 I d$. ("[I]t's important to remember why infrastructure has become a hot topic now. The economy already appears to be in its worst recession in a generation. Without a major stimulus package, it could get a lot worse next year. So now isn't the time to overhaul the entire system. Speed matters.”). 
to be corrected. In either case, this process of post-decision screening would allow Congress to determine whether to continue to fund projects that are already underway.

While by no means the cure to all of our fiscal problems, the proposed Growth Budgeting Board could provide useful information for Congress to take into account in setting its budget. Much institutional detail obviously remains to be determined, but as a starting point, the GBB offers the promise of bringing needed professional expertise to the process of determining whether to spend money on short-run stimulus and on projects that offer potential long-term returns that could benefit us all in the future.

\section{CONCLUSION}

The U.S. government has, for almost eighty years, taken an active role in trying to end and reverse economic downturns, reflecting a commitment to maximize the economic well-being of its citizens in the short run. In addition, one of the core concerns of government budgeting is the impact that decisions to spend and tax today will have on living standards in the long run. Given the recent severe economic recession and its painful, ongoing aftermath, and given opportunities to spend government funds on projects with long-term benefits - such as cancer research, education at all levels, technology incubation, high-speed rail, advanced electrical grids, and so on - I propose that the U.S. federal government create a Growth Budgeting Board (GBB). The GBB would be empowered as an independent government agency, to guide government budgeting decisions in both the short run and the long run.

In the short run, the GBB would identify spending that can be justified as a short-term response to an economic downturn, allowing the government to run "good deficits" that would bring the economy back to health as quickly as possible. In addition, the GBB would adopt a variation on capital budgeting described herein as Growth Budgeting. Such an accounting system would permit the GBB to determine which projects provide no long-term benefits (and therefore must be financed by current taxation), and which projects can (because they will create benefits in the future that exceed borrowing costs) be financed through annual deficit spending. That is, it could identify "good deficits" that raise long-run growth. Administered in a principled way, a Growth Budgeting system could result in higher future living standards, even when the government increases its outstanding debt each year.

The potential danger in adopting a Growth Budget lies in its ability to make some spending projects appear to be less expensive than they actually 
are. If an item is included on a capital budget, this frees legislators to approve the item without making the difficult choices necessary to fund a project from current revenues. Therefore, it is necessary to discipline this process by adopting safeguards to insure that the Growth Budget will include only items that are truly worthwhile long-term investments. After discussing a range of possible administrative systems that could prevent such abuse, ranging from one-time expert commissions to full-scale adjudicative processes, this article concludes that creating the proposed GBB would be the best method to discipline a Growth Budgeting system.

The central messages of this article are that the federal government must continue to be actively involved in ending recessions, and that it is possible to adopt modern methods of budget accounting (already common in the private sector and in other governments) that will guide spending decisions away from waste and toward projects that will improve living standards, today and in the future. While there are many areas of reasonable disagreement over the administrative details involved in adopting the proposed reforms, those details should not prevent us from making concrete progress in our efforts to have the government spend responsibly, now and in the future. 